\title{
INTERNATIONAL CAPITAL INFLOWS, DOMESTIC FINANCIAL INTERMEDIATION AND FINANCIAL CRISES UNDER IMPERFECT INFORMATION
}

\author{
Menzie D. Chinn \\ Kenneth M. Kletzer \\ Working Paper 7902 \\ http://www.nber.org/papers/w7902
NATIONAL BUREAU OF ECONOMIC RESEARCH 1050 Massachusetts Avenue
Cambridge, MA 02138
September 2000

\begin{abstract}
We are grateful to the participants at the Federal Reserve Bank of San Francisco Conference on "Financial Crises in Emerging Markets," (September 1999) and the editors for their helpful comments. The views expressed here are those of the authors and do not reflect those of the institutions with which the authors are affiliated.

(C) 2000 by Menzie D. Chinn and Kenneth M. Kletzer. All rights reserved. Short sections of text, not to exceed two paragraphs, may be quoted without explicit permission provided that full credit, including (C) notice, is given to the source.
\end{abstract}


International Capital Inflows, Domestic Financial Intermediation and Financial Crises under Imperfect Information

Menzie D. Chinn and Kenneth Kletzer

NBER Working Paper No. 7902

September 2000

JEL No. F31, F41

\section{$\underline{\text { ABSTRACT }}$}

A model of financial crises in emerging markets based on problems of agency in financial intermediation is developed. This model generates dynamic relationships between foreign capital inflows, domestic investment and domestic bank debt in an endogenous growth model. As a consequence of loan renegotiation between limited liability banks and firms, financial crises inevitably occur. Banking and currency crises are concurrent events under an exchange rate peg combined with deposit insurance and implicit government guarantees of foreign currency loans. The model links high pre-crisis growth rates, the accumulation of bank debt and increasing concentration of domestic lending and investment to the anticipation of contingent government insurance of private financial transactions. The dynamics of capital inflows and growth before and after a financial crisis are compared to the experience of the Asian crisis countries. We find evidence consistent with this agency model of domestic bank intermediation of foreign capital inflows under exchange rate pegs.

Menzie D. Chinn

Department of Economics

Social Sciences I

University of California

Santa Cruz, CA 95064

and NBER

chinn@cats.ucsc.edu
Kenneth M. Kletzer

Department of Economics

Social Sciences I

University of California

Santa Cruz, CA 95064

and

International Monetary Fund

kkletzer@cats.ucsc.edu 


\section{Introduction}

Recent financial crises in emerging markets have been preceded by periods of large capital inflows and expansions of the domestic banking sector. In the aftermath of these crises, economic growth has fallen sharply and, in some cases, been slow to recover. Many of the recent crises have been associated with implicit guarantees by sovereign governments of foreign currency debts accumulated by the private sector. Recently several economists, notably Calvo [1998a], have observed that these crises evolve through complicated interactions between domestic financial sectors, international lenders and national governments. Financial crises have often been characterized by concurrent banking and currency crises. ${ }^{1}$ Recent experience suggests that banking crises are not necessarily just an outcome of a collapsing exchange rate regime. Instead, the source of a financial crisis may be found in the interaction between the microeconomics of private financial intermediation and government macroeconomic policies.

In this paper, we propose a theoretical model of the dynamics of bank lending, domestic production and the accumulation of foreign currency liabilities by domestic financial intermediaries that ultimately lead to a financial crisis. These dynamics derive from the introduction of an agency problem in domestic financial intermediation that originates in an informational advantage for domestic banks in domestic lending and government provision of insurance to private financial activities. The equilibrium for the model economy predicts twin banking and currency crises that end a period of high gross domestic output growth and inflows of foreign capital. Before the crisis occurs, capital inflows rise with domestic production while private foreign debt grows more rapidly than output. Output contracts at the time of the crisis, as capital suddenly flows outward, and has a lower trend growth rate post-crisis than pre-crisis. These predictions are compared with the data for the East Asian crisis countries in the second part of the paper.

In our model, the loan portfolio choices of banks are subject to adverse selection in the presence of government deposit insurance for domestic savers and guarantees of foreign currency loans for foreign creditors with insufficient monitoring. The economy is represented by a simple endogenous growth model in which the productivity for each firm is stochastic. Banks intermediate lending to firms. The banking system becomes progressively more indebted through foreign borrowing until it is ultimately insolvent. This process ends in a government bailout of foreign creditors and domestic depositors. The 
anticipation of the bailout induces the trend debt accumulation that ultimately triggers the crisis and bailout.

As argued by Calvo [1998a], following the literature on sovereign debt, a sovereign government has an incentive to subsidize foreign capital inflows to overcome the problem of its own moral hazard in setting trade, fiscal and monetary policies. We observe that government guarantees of foreign currency obligations incurred by the private sector are typically associated with the abandonment of an exchange rate peg. Government insurance that at least partially indemnifies foreign investors in the event of devaluation appears to be an implicit part of a pegged exchange rate regime, as noted by Mishkin [1996] and Obstfeld [1998]. Our model links a banking crisis with a currency crisis by adopting this form of contingent government subsidization of foreign lending. ${ }^{2}$

When a currency crisis occurs, the government realizes a sudden increase in its outstanding liabilities. The exchange rate regime collapses because the ultimate monetization of these liabilities is anticipated by market participants. The contingent liabilities of the government are endogenously accumulated through the foreign capital inflows induced by the public sector guarantees of private foreign currency debt. Because the size of the government liabilities is endogenous, the timing of the collapse is indeterminate in this model. The role of contingent public sector liabilities for generating currency crises has been emphasized by Calvo [1998a and b], Burnside, Eichenbaum and Rebelo [1999] and Dooley [1999]. Our model adds the role of agency in domestic intermediation to generate the endogenous dynamics of output growth, capital inflows, banking sector insolvency and currency crisis. In our economy, banking crises and currency crises are the inevitable consequence of financial and capital account liberalization in the presence of debt guarantees and an exchange rate peg.

Many authors have offered various explanations for the financial crises in East Asia in 1997. ${ }^{3}$ Our approach emphasizes the relationship between large foreign capital inflows and high output growth and the ultimate collapse of the domestic financial sector along with the exchange rate regime. The currency crisis and realization of losses by the domestic financial intermediaries coincide, but the timing of this event is indeterminate.. This leaves room for the simultaneity of crises across countries to be explained by panic or contagion models. ${ }^{4}$ The source of the financial crises generated by our model are fundamentals and contrast with liquidity crisis view presented by Chang and Velasco [1999], Goldfajn and Valdes [1997] and others. 
Section 2 presents the theoretical model and its implications. Our model of bank intermediation with limited liability firms is distantly related to that of Kiyotaki and Moore [1997] but contrasts with their model sharply in that loans can and will be renegotiated in our economy. The empirical implications of the model are summarized at the end of the section.

Section 3 compares the predictions of the model to the data for the Asian crisis countries with broad success. The last section concludes.

\section{A Theoretical Model of Financial Crises}

We model international capital flows and domestic banking in an infinitely-lived small open economy. Households and firms are represented by entrepreneurs who establish firms, save and consume. A fixed number of these entrepreneurs operate banks. These banks intermediate between domestic and foreign savers and domestic investors. We set up the behavior of each of these agents and of the equilibrium dynamics for the economy in sequence.

\subsection{The Economy}

There is a single good that can be consumed, invested or traded internationally. It can be produced using entrepreneurial labor and capital. Capital in this model should be thought of as working capital; it is exhausted in the production process. Output is stochastic, and production takes one period.

All residents have identical preferences over infinite-horizon consumption plans and are endowed with a single unit of labor each period. Each person is a potential entrepreneur who can invest in a project each period. The investment opportunities available to different people need not be the same, allowing entrepreneurs to be heterogeneous with respect to skills or knowledge. For example, a subset of entrepreneurs are able to operate banks. The services provided by banks will be defined below. The technique of production available to each entrepreneur does not change over time.

Each firm uses one unit of entrepreneurial labor and is identified with a particular entrepreneur. Goods production displays constant returns to capital and increasing returns to entrepreneurial effort. Production is risky. The projects available to different entrepreneurs vary with respect to the distribution of output produced across states of nature. For example, the output distribution per unit of capital for one entrepreneur's project may have higher variance and mean than that for another entrepreneur. 
The output realized in any period by an individual firm is private information that can be observed by others at a fixed cost per observation. Banks operate a technology that allows them to observe project outcomes at a lower cost than others. This inhibits direct equity investment by individuals in the projects undertaken by other entrepreneurs and encourages lending using conventional debt contracts by banks. The optimality of conventional loan contracts under costly observability is demonstrated by Diamond [1984]. Because the cost of observing actual outcomes for individual firms are fixed, there is a cost advantage to having a single bank make loans to a particular entrepreneur. Therefore, the role of banks in this model is to diversify income risk for individual savers in the presence of moral hazard in reporting firm earnings.

Individuals are risk averse and smooth consumption over time. A household seeks to maximize utility,

$$
U_{t}=E_{t} \sum_{s=t}^{\infty} \beta^{s-t} u\left(c_{s}\right),
$$

where $u(c)$ is strictly concave and $0<\beta<1$, with respect to their consumption plans given the intertemporal budget identity,

$$
w_{s+1}-w_{s}=i_{s}^{d} w_{s}+\pi_{s}-c_{s}
$$

solvency condition,

$$
\lim _{s \rightarrow \infty} w_{s} \prod_{v=t}^{s-1}\left(\frac{1}{1+i_{v}^{d}}\right) \geq 0
$$

and initial financial wealth, $w_{t}$. Here, $w$ indicates deposits held in banks, $\pi$ represents entrepreneurial income from production and $i^{d}$ is the deposit rate of interest. We assume that money is required to make consumption purchases and that domestic transactions are denominated in units of domestic currency. Demand deposits pay a positive rate of return so that money is held only as deposits in equilibrium. In this economy, the government provides deposit insurance so that the domestic currency value of household claims against banks is fully insured. ${ }^{5}$

Entrepreneurs can finance investment by borrowing from banks or using their own savings. Entrepreneurial income is the residual of the stochastic gross returns to investment after the firm's current debt obligation is satisfied. When the returns to investment are insufficient to meet the debt repayment obligation, the firm reports this to the bank which in turn expends the fixed cost, $c$, to verify actual returns. In this event, the firm and the bank can agree to rollover the unpaid debt or to declare the firm bankrupt. Bankruptcy is assumed to be costly for the entrepreneur. She cannot simply abandon her 
debt and return to the loan market. The bank and the firm will rollover loans under these circumstances.

The production function for firm $j$ is given by

$$
y_{t}^{j}=r_{t}^{j} k_{t}^{j},
$$

where $k_{t}^{j}$ is the investment undertaken by firm $j$ in period $t-1$. Capital depreciates fully. $r_{t}^{j}$ is the stochastic (marginal and average) productivity of capital. $r_{t}^{j}$ is non-negative and distributed identically and independently across time.

The firm's debt, $d^{j}$, evolves as

$$
d_{t+1}^{j}=\left(1+i_{t+1}^{j}\right)\left(d_{t}^{j}+\ell_{t+1}^{j}-\rho_{t}^{j}\right),
$$

where $i_{t+1}^{j}$ is the borrowing rate of interest for firm $j$ and $\ell_{t+1}^{j}$ is the amount of new funds lent by the bank in period t. $\rho_{t}^{j}=\max \left\{d_{t}^{j}, r_{t}^{j} k_{t}^{j}\right\}$. Therefore, $d^{j}$ is always non-negative; entrepreneurs lend to banks through household deposits. The terms of the new loan made at time $t, \ell_{t}^{j}$ and $i_{t}^{j}$, are determined after $\rho_{t}^{j}$ is known. Competition between banks will determine the rate of interest charged a firm with no existing debt overhang. The specifics of loan rollovers are discussed below.

Entrepreneurial income is given by

$$
\pi_{t}^{j}=\max \left\{r_{t}^{j} k_{t}^{j}-d_{t}^{j}, r_{t}^{j}\left(k_{t}^{j}-\ell_{t}^{j}\right)\right\},
$$

where $k_{t}^{j}-\ell_{t}^{j}$ is the share of the investment undertaken by the firm in period $t-1$ that was self-financed. Firms are modelled as corporations in that owners' assets held outside the firm cannot be claimed by the firm's creditors. Limited liability for firm owners is displayed by equation (6). The consequence of costly observability and limited firm liability is that entrepreneurs cannot purchase insurance against income risk. They share risk by borrowing from banks using conventional loan contracts with bankruptcy (as demonstrated by Diamond [1984]).

International financial capital inflows equal the current account deficit plus the increase in central bank reserve holdings through the balance of payments identity. Private foreign borrowing is intermediated by domestic banks. The current account surplus is given by

$$
b_{t+1}-b_{t}=i_{t}^{*} b_{t}+y_{t}-c_{t}-k_{t+1} .
$$

The current account equation is written in units of foreign currency. Nominal prices are perfectly flexible, and purchasing power parity holds. Uncovered interest parity also holds, so that if the exchange rate is fixed, $i_{t}^{*}$ and $i_{t}^{d}$ will be equal. 
We consider fiscal policy only in its role for generating a currency crisis under a pegged exchange rate regime. Therefore, there are no public expenditures and all governments revenues are collected through money creation. Any transfers are fully monetized leading to a one-for-one increase in domestic credit. Any transfers will be contingent and paid as government guarantees to creditors.

\subsection{Dynamics of bank lending}

In this section, we consider the dynamics of domestic bank lending and firm debt taking the nominal rate of interest on deposits as constant. That is, the exchange rate is fixed.

Bankers have the incentive to rollover debts that client firms are not able to repay in any current period. If the bank ever desires to make a loan to firm $j$,

$$
E_{t}\left[\left(r^{j}-\left(1+i^{*}\right)\right) u^{\prime}\left(c_{t+1}\right)\right] \geq 0
$$

when the bank is solvent with certainty, where $c_{t+1}$ is the bank entrepreneur's consumption in period $t+1$. The inequality is strict unless the interest rate charged is high enough to exhaust the firm's revenues with probability one. When the probability that the bank becomes bankrupt is positive, the expectation is conditional on the event that bankruptcy does not occur. If a bank receives $r^{j} k_{t}^{j}<d_{t}^{j}$ from firm $j$ in period $t$, then the bank can add the difference, $d_{t}^{j}-r^{j} k_{t}^{j}$, to new loan it makes in period

$t, \ell_{t}^{j}$. For events such that $r_{t+1}^{j} k_{t+1}^{j}>\left(1+i_{t+1}^{j}\right) \ell_{t}^{j}$, the bank receives repayment of part of the rolled over debt from period $t$. This additional return is possible because the bank can declare the firm bankrupt and bankruptcy is costly for the firm. To limit the market power of the bank, we impose the institutional assumption that bank can only charge the same initial rate of interest in a rollover. Making this arbitrary assumption simplifies the model. The opportunity cost of the new loan is $\left(1+i^{*}\right) \ell_{t}^{j}$.

Figure 1 depicts return per unit of new funds, $\ell^{j}$, for the bank when its client's debt rollover equals $d^{j}$ and the lending rate of interest is $i^{j}$. The expected return for the bank is given by $\ell^{j} E\left(r^{b}\right)$ where

$$
r^{b}=\min \left\{r^{j},\left(1+i^{j}\right)\left(1+\frac{d^{j}}{\ell^{j}}\right)\right\}-\left(1+i^{*}\right),
$$

when the probability the bank becomes insolvent in the period is zero. Here, $k^{j}=\ell^{j}$ for simplicity (we impose this condition because it makes no difference for the dynamics of interest below ${ }^{6}$. For any given size investment, $\ell^{j}$, this expression is increasing in $d^{j}$. The bank also incurs a cost, $c$, in the event 
that

$$
r^{j}<\left(1+i^{j}\right)\left(1+\frac{d^{j}}{\ell^{j}}\right)
$$

Suppose that $d_{t}^{i}=0$ for each client firm $i$ of the bank and that the bank's loan portfolio is optimally allocated at the beginning of period $t$. The bank's portfolio at the beginning of period $t+1$ satisfies the Euler conditions given by

$$
E_{t}\left[u^{\prime}\left(c_{t+1}\right)\left(\min \left\{r_{t+1}^{i},\left(1+i^{i}\right)\left(1+\frac{d_{t+1}^{i}}{\ell_{t+1}^{i}}\right)\right\}-\left(1+i^{*}\right)-c_{t+1}^{i}\right)\right]=0
$$

for each client firm $i$ (equality holds for an interior solution) where $c_{t+1}^{i}$ is the random variable that equals $c$ when $r_{t+1}^{i}<\left(1+i^{i}\right)\left(1+\frac{d_{t+1}^{i}}{\ell_{t+1}^{i}}\right)$ and zero, otherwise. Consider the case that the productivity of capital for firm $j$ in period $t, r_{t}^{j}$, falls below $\left(1+i^{j}\right)$, but $r_{t}^{i} \geq\left(1+i^{i}\right)$ for each $i \neq j$. By equation (5), $d_{t}^{j}>0$ while $d_{t}^{i}=0$ for $i \neq j$. The Euler conditions (11) imply that the bank's choice of $\ell_{t+1}^{j}$ will rise relative to loans to other firms, $\ell_{t+1}^{i}$, in comparison to the portfolio held in period $t$. For example, if the total size of the bank's loan portfolio remains constant between periods $t$ and $t+1, \ell_{t+1}^{j}>\ell_{t}^{j}$ and $\ell_{t+1}^{i}<\ell_{t}^{i}$ for $i \neq j$.

The extent to which the bank's portfolio shifts toward loans to firm $j$ depends on the magnitude of $d_{t+1}^{j}$, the joint distribution of all the $r^{i}$ and the degree of risk aversion of the bank entrepreneur. If the $r^{i}$ are perfectly correlated for the bank's clients, then the bank shifts its entire portfolio to the borrower that first realizes revenues less than current debt service. If the $r^{i}$ are imperfectly correlated, the relative increase in $\ell_{t+1}^{j}$ declines with the bank entrepreneur's relative risk aversion (the bank's portfolio allocation problem is just the consumption-based capital asset pricing model).

Figure 1 also shows that the probability that $d_{t+2}^{j}$ exceeds $d_{t+1}^{j}$ is given by

$$
\operatorname{Pr}\left\{d_{t+2}^{j} \geq d_{t+1}^{j}\right\}=\operatorname{Pr}\left\{r^{j} \leq\left(1+i^{j}\right)\left(1+\frac{d_{t+1}^{j}}{\ell_{t+1}^{j}}\right)\right\},
$$

using equation (5). This probability is rising in the ratio $d_{t+1}^{j} / \ell_{t+1}^{j}$. Therefore, the probability that firm $j^{\prime} s$ share in the loan portfolio rises again between periods $t+1$ and $t+2$ is increasing in firm $j^{\prime} s$ portfolio share in period $t+1$. In the case that the total amount lent by the bank remains constant, $E_{t+1}\left(\ell_{t+2}^{j}\right)>\ell_{t+1}^{j}$.

The result is that the variance of the rate of return to the bank's entire portfolio rises over time, in expectation, when the $r^{i}$ are i.i.d. and imperfectly correlated. Because the probability that the debt of any individual borrower rises during a period is an increasing function of the beginning of period 
indebtedness of the borrower, the bank's portfolio becomes less diversified over time with positive probability. The expected increase in the riskiness of the bank's portfolio rises with time.

Thus far, we have imposed the restriction that the bank entrepreneur bears all the risk of bank's portfolio allocation. This is reflected in equation (11). However, in our model the bank has limited liability for repayment of its debts. The conditions (11) and (12) imply that the variance of the returns to the bank's loan portfolio rise stochastically over time. The deposit liabilities of the bank, $b_{t}$, follow

$$
b_{t+1}=\left(1+i^{*}\right)\left(b_{t}+\ell_{t}-\omega_{t}\right),
$$

where $\ell_{t}$ is the total amount of new loans made and $\omega_{t}$ is the total withdrawal of deposits in period $t$. The net deposits of households equal $\ell_{t}-\omega_{t}$ for a closed economy. These equal total household savings in period $t$ which depends upon the distribution of entrepreneurial incomes.

When actual aggregate output, $r k$, is less than the opportunity cost of investment, $\left(1+i^{*}\right) k$, net demand for withdrawals from the banking sector exceeds the current resources of the banking system (because income and output are equal). This is a consequence of consumption smoothing implied by household optimization (equations (1), (2) and (3). At least one bank must be illiquid - current gross repayments from its client firms are less than net withdrawals.

In this model, such a bank still holds real assets. These are the claims to the repayment of old debts by its client firms. The difference between bank liquidity and solvency arises here because rolled over firm debts have positive value. This contrasts with time-to-build models based on Diamond and Dybvig [1983], such as Chang and Velasco [1999].

Consider two possible actions for the government in this circumstance. It can shut down the bank and sell its assets to other banks. Or, it can become a creditor of the bank, imposing repayment of the shortfall paid by deposit insurance on the bank while allowing the banker to continue operating. Either solution limits the liability of the bank and leads it to choose a riskier loan portfolio ex ante. Figure 2 shows the distribution of net income for a bank under the second policy. $d^{b}$ is the bank's debt (to households and government), $d$ is the total debt of the bank's clients and $r^{b}$ is the return to the bank's loan portfolio net of costs of monitoring firm incomes and gross of debt repayments. The bank realizes the positive income,

$$
\pi^{b}=\ell\left[\min \left\{r,(1+i)\left(1+\frac{d}{\ell}\right)\right\}-\left(1+i^{*}\right)\left(1+\frac{b}{\ell}\right)\right],
$$


for

and zero otherwise.

$$
r>\left(1+i^{*}\right)\left(1+\frac{b}{\ell}\right)
$$

An increase in $b$ will induce the bank entrepreneur to choose a riskier portfolio among portfolios offering the same mean return. This is a consequence of conditions (11) and (12). An increase in $b$ leads to adverse selection in the choice of the bank's portfolio from the perspective of the government (as the bank's creditor). This follows from the analysis of Stiglitz and Weiss [1981] of an increase in the interest rate charged to a risk neutral agent. Although, our bank entrepreneur is risk averse and makes a more complex choice, the analysis clearly still applies.

The end result of these intermediate results is that the variance of a bank's income rises stochastically; it follows a submartingale as bank portfolios become more concentrated. The unconditional probability of individual firm illiquidity rises over time as firm indebtedness is self-reinforcing (the probability of a debt increase rises with existing indebtedness). If the support of the distribution of $r^{i}$ for each firm $i$ is bounded from above, then firms eventually become insolvent in this economy. This carries through to banks. Eventually, the probability of insolvency for each bank rises towards one in this economy.

\subsection{Foreign lending and domestic financial intermediation}

We next consider this banking sector in the open economy. Domestic banks intermediate between foreign and domestic creditors and domestic firms. The banks have a cost advantage over foreign lenders in observing the realized outputs of domestic firms. This advantage is assumed to be large enough to preclude any direct foreign portfolio lending to domestic entrepreneurs. However, foreign lenders face the risk of bankruptcy by domestic banks in the absence of government intervention. In this case, foreign lenders should charge domestic banks a risk premium over the international rate of interest.

Foreign creditors also face sovereign risk; the government chooses the monetary growth rate, hence the rate of depreciation. Loans denominated in domestic currency are proportionately reduced in real terms when the currency depreciates or is devalued. Foreigners have a strong incentive to not hold net claims in domestic currency. If foreign creditors write loans denominated in foreign currency, they still face the risk of losses due to exchange rate changes because domestic banks lend in domestic currency. This is a consequence of the limited liability of domestic banks. A devaluation that is not 
fully anticipated reduces the return to banks in terms of foreign currency. If a domestic bank becomes bankrupt as a result, then its foreign creditors realize real losses. Under limited liability, the domestic banker will not desire to fully hedge against currency risk because some of the gains from doing so accrue wholly to foreign creditors.

As a consequence of sovereign risk, capital inflows will be inefficiently low and the government has an incentive to intervene. One way to address this problem is to peg the nominal exchange rate and guarantee repayment of foreign currency loans contingent on devaluation. We adopt this policy regime not because it is optimal (it surely is not in general), but because it is the kind of policy adopted by East Asian countries before the crisis. Under a fixed exchange rate with contingent foreign currency liability guarantees, Burnside, Eichenbaum and Rebelo [1999] demonstrate that foreign currency loans are not hedged. In this policy regime, foreign lenders still face the risk of debtor insolvencies when lending to domestic banks. They are not insured by the government against bank insolvencies that do not occur simultaneously with devaluation.

We will assume that the return to foreign lenders in the event of a bailout by government following a currency crisis is $i^{*}$, the international rate of interest. This assumption can be relaxed to allow losses to foreign lenders in a financial crisis at the cost of complicating the analysis. In our model economy, foreign creditors will have an incentive to keep banks going until the moment of a crisis. At the time of a crisis, foreign lenders will be better off becoming creditors of the government and not of domestic banks.

To see this, consider the decision of a foreign lender. If a bank is illiquid at date $t$ and has foreign debt, $f_{t}$, then its foreign creditors can assure themselves an eventual rate of return equal to $i^{*}$ on any loans they make by lending more to the bank if an eventual currency crisis is assured. Since banks become illiquid eventually with probability one in our model, bank foreign debt will rise over time. Bankers will demand additional foreign capital inflows every time one of their client firms realizes a poor investment outcome. This follows from the Euler condition for the individual bank, equation (11), as depicted in Figure 1. As total bank notional assets, $d$, rise, so does the bank's demand for foreign inflows. Forcing an idiosyncratic bank failure yields a loss for foreign creditors that continuing to lend given eventual devaluation does not. 
Foreign lending to domestic banks covers the difference,

$$
-\pi^{b}=\ell\left[\left(1+i^{*}\right)\left(1+\frac{b+f}{\ell}\right)-\min \left\{r,(1+i)\left(1+\frac{d}{\ell}\right)\right\}\right],
$$

when positive, and increases in the size of its loan portfolio induced by rises in the debts, $d^{i}$, of the bank's client firms. In equation (15), $b$ denotes the face value of domestic deposits and $f$ the foreign debt of the bank.

Because firm debt is an increasing random variable, capital inflows must be rising, stochastically, over time. Output is rising proportionately with inflows that fund investment in this endogenous growth model $(y=r k)$. Each time a firm's output is less than its debt, inflows and investment rise in equilibrium. Consumption is also rising along with income (although not proportionately for the general

concave utility function, $u(c))^{7}$. In addition, the probability that a bank cannot meet the net demands of domestic depositors is rising over time as its portfolio becomes riskier. Whenever banks borrow from abroad to meet net domestic deposit withdrawals, the loans are financing consumption not investment. Since this occurs with positive (and increasing) probability, the foreign debt of each bank as a ration of its lending, $f / \ell$, is an increasing random variable (a submartingale). Therefore, foreign debt is rising (stochastically) as a ratio of gross domestic product. Also, because $f / \ell$ is monotonically increasing in expectation for the individual bank, individual banks become insolvent eventually with probability one.

\subsection{Currency and banking crises}

The arguments for these dynamics are conditional on an eventual government bailout of foreign lenders. This policy response is assumed to be contingent on devaluation. The resources available to the government to pay foreign lenders in a bailout are finite. Therefore, there is an upper bound on the credit extended by foreigners to domestic banks. This is the sum of the debt guarantee of the government and of the residual resources of the debtor banks plus central bank reserves in the event of a financial crisis. In this model economy, this upper bound is reached in finite time with probability one as a consequence of the bank debt rollover dynamics in the previous subsection.

The mechanics of a crisis are as follows. Let the maximum amount of the government bailout of foreign currency debts equal $\bar{D}>0$. Eventually, the foreign debt of the banking sector will exceed the value of the banking sector plus central bank reserves minus domestic deposits. ${ }^{8}$ This excess claim at time $t$ is denoted by $D_{t}$. $D_{t}$ is stochastic. If a run occurs in period $t$, the resources to pay $D_{t}$ in 
present value will be raised through monetization. The expected rate of depreciation after the crisis is an increasing function of $D_{t}$, so that the drop in money demand by domestic households at the moment of a crisis is increasing in $D_{t}$. Therefore, the portion of reserves taken in a currency crisis by parties other than foreign currency creditors equals the fall in domestic currency deposit demand and is given by $R_{t}^{d}=\psi\left(D_{t}\right)$, where $\psi^{\prime}\left(D_{t}\right)>0$. The reserves claimed by foreign holders of short-term foreign currency bank debt are equal to $R_{t}^{f}=B_{t}-D_{t}$. The sum of $R_{t}^{d}$ and $R_{t}^{f}$ equals the maximum of total foreign reserves and the amount of these that the central bank commits to defend the currency peg, $\bar{R}_{t}$.

The relationship that is satisfied at the time of a twin banking and currency crisis is

$$
\bar{R}_{t}=R_{t}^{d}+R_{t}^{f}=B_{t}-D_{t}+\psi\left(D_{t}\right)
$$

which has a continuum of solutions, $B_{t}\left(D_{t}\right)$. The currency crisis occurs on or before the date that foreign currency debt attains the maximum amount that foreign creditors can expect to be repaid. If the government honors the international rate of interest on foreign currency loans (as assumed), then the attack can happen at any time that $D_{t}>0 . D_{t}$ simply has to be large enough to generate an ex post inflation rate inconsistent with the existing exchange rate peg. Because $D_{t}$ is endogenous, the timing of the attack is indeterminate once $D_{t}$ is positive. ${ }^{9}$

This model does not have equilibria in which lending and ultimate financial crises do not occur under a simple condition on the productivity of capital. If foreign lenders did not anticipate an attack and bailout, they would lend if

$$
E[\max \{1+i, r\}]-c^{f} \operatorname{Pr}\{r<1+i\}=1+i^{*} .
$$

This has a solution for $i$ when $d$ is zero. This condition assures that a profitable loan can be made when the lender commits to take what she can after one period, where $c^{f}$ is the foreign lender's cost of observing a domestic bank's portfolio return, $r$. If the foreign lender rolls over unpaid debt service, then her ex ante return increases. Therefore, foreign loans will be made. Eventually, the crisis occurs.

\subsection{Crisis aftermath}

When the financial crisis occurs, there is a sudden reversal of capital inflows as foreign lending halts and domestic savers seek foreign assets. Domestic lending and output contract sharply in the model economy. Lending will resume under the floating regime if the banks are left to operate. The government implicitly partially bails out the private domestic financial sector in the equilibrium of 
the model because it takes over the foreign debt. It can also forgive any deposit insurance indemnity payments during the crisis. The banks will be able to borrow from domestic households and foreign lenders. The return to domestic residents for holding domestic or foreign assets is the same under uncovered interest parity if the government continues to provide deposit insurance.

Foreign lenders, however, have exhausted (partly or in whole) the resources that the government can commit to an eventual bailout $(\bar{D})$. The government cannot offer the same guarantee. Foreign creditors still offer loans to domestic banks given condition (16). Without the implicit subsidy from the government, foreign financial capital inflows will be less than before at any level of bank claims against domestic firms, $d$. Output must contract and grow more slowly than before the crisis as foreign capital inflows are no longer subsidized.

If the government does not bail out the domestic financial sector, the growth rate of output in recovery can be lower as a consequence of the loss of bank intermediation. The loss of domestic banking would force the use of alternative, higher cost, means of intermediation. If banks operate with an overhang of debt to the government, then, as shown by the conditions for a bank's optimal portfolio choice, domestic loan portfolios will be riskier. Calvo [1998a] makes the general point that the loss of bank services can result in a further output contraction by disrupting the payments mechanism. Lastly, we have assumed full nominal price flexibility. If this fails, the output effects could be exacerbated by the consequent real exchange rate movements.

\subsection{Empirical implications of the model and extensions}

Our theoretical model implies that banking and currency crises coincide and occur with probability one in the absence of effective prudential regulation. Before the crisis, private foreign debt rises as a ratio of gross domestic production. Foreign financial capital inflows will be a constant fraction of trend output in the case that consumption growth equals income growth. Otherwise, the ratio of inflows to output can rise or fall in trend. The shadow value of domestic banks should be declining before the crisis. This could be measured by comparing the stock market value of domestic banks to the stock market value of the domestic sector. Bank capital should be decreasing over time.

After a financial crisis, the model implies that output contracts and that the growth rate of output is lower in recovery than it was before the crisis. This is because the contingent government bailout has been exercised so that the resources that previously subsidized foreign capital inflows are no 
longer available to subsidize new inflows at the same level. The currency crisis should also lead to a contraction in money demand and an increase in the rate of monetary growth. The second is consistent with the monetization of the sudden increase in government liabilities. This is the mechanism by which a currency crisis occurs in our model, so we need to check if it arises in the empirical record.

The riskiness of the loan portfolio of domestic intermediaries is rising in this model. An increasing share of bank loans go to firms that have realized low capital productivities in the past, while a decreasing share go to firms that have realized high productivities of capital. In the endogenous growth model used, the productivity of capital is an i.i.d. random variable. If we allow for a small degree of serial correlation in the productivity of inputs for individual firms, then the marginal productivity of capital in the aggregate will be decreasing in trend.

Possible extensions of the basic model could allow firms to choose riskier projects as they become more heavily indebted. Banks would then face adverse project selection by firms. Following Bernanke and Gertler [1989 and 1990], banks would require firms to partially self-finance investments. However, in our framework banks would relax self-financing requirements and the projects selected by individual firms would become riskier as individual firm debt rises. That is, banks would choose a riskier portfolio both by concentrating lending more on firms rolling over unpaid past debts and by allowing firms to choose riskier projects. In such a more complicated, two-tier agency model, the investments chosen by firms could become riskier simultaneously with bank portfolios as part of the same optimal portfolio behavior under limited liability for banks. This is another reason that capital to output ratios might rise before financial crises. In addition to the strict implications of the model as written, we also investigate the data for this possibility.

\section{Empirical Evidence for the Model}

\subsection{A first pass at the data}

Formal testing of the model is hampered by the unavailability of data for many of the variables of interest. Indeed some of the key variables in the model are not directly observable. These are the riskiness of investment, the size of the contingent liabilities and the share of bank capital (as opposed to foreign capital) in domestic investment. 
The model, however, can be examined along a number of dimensions using indirect measures of the factors of interest. In this informal examination, we discuss the patterns that can be observed, and whether they conform to the model. The model incorporates a number of important assumptions and implies several relationships. The key condition is that increases in capital inflows are intermediated through the banking system and result in increases in lending to the private sector. This is the case to the extent that capital inflows to the domestic banking sector are not sterilized, resulting in reserve accumulations rather than financing debits on the current account.

The patterns we expect to observe for economies subject to these agency problems include the following:

1. An increasing ratio of foreign and domestic lending as a ratio of output.

2. Capital inflows rising with GDP for crisis countries; the ratio of inflows to GDP can be rising.

3. Increasing riskiness of domestic investment; this may be reflected in falling capital productivity.

4. Deterioration of bank portfolios as the share of non-performing assets rises.

5. Post-crisis increases in money supply growth rates.

Each of these factors is examined in turn.

\subsubsection{Capital inflows and domestic lending}

The model requires that capital inflows are manifested in lending by banks and other financial intermediaries. We do not present a detailed discussion of how effective these countries have been in sterilizing capital inflows; such accounts are provided by Spiegel [1995] and Moreno [1996]. Rather we focus on the broad relations between capital inflows and lending over the pre-crisis period. We measure capital flows using the financial account data reported by the IMF (in US\$ converted to domestic currency), while deposit bank lending to the domestic private sector is measured by domestic credit (IFS line 32d). For certain countries, additional lending is provided by non-deposit taking banks and nonbank financial institutions; we will refer to the sum of deposit bank lending and these additional categories as total lending (as opposed to bank lending). In Figures 3-9, scatterplots of the relationship between changes in bank lending and capital inflows (in billions of units of domestic currency) are presented for Indonesia, Korea, Malaysia, Philippines, Singapore, Taiwan and Thailand for the 1985.1-97.1 period (annual data are plotted for Malaysia and Singapore). In all cases, save Singapore and Taiwan, the slope coefficient is positive in a simple regression of bank lending changes and capital inflows. Typically the 
coefficient is above 0.5 , but below 1.00. One might think that some of the effect is omitted since we only allow for contemporaneous effects; however, most of the impact of capital inflows appears to be manifested within one quarter.

Singapore and Taiwan are interesting exceptions. These two economies ran substantial and persistent current account surpluses, and for certain periods Taiwan exports financial capital. Whatever increase there is in financial intermediation through the banking system, it is not driven by capital inflows.

\subsubsection{Surges in bank lending}

Much has been made of the role of rapidly increasing bank lending in the years leading up to the 1997 crises. More recently, Moreno [1999] has argued that only in certain cases were movements in domestic credit in excess of historical averages in the period immediately preceding the July 1997. Analysis of whether there was a surge in bank lending is complicated by the fact that developing countries typically exhibit rising bank loan to GDP ratios, as the process of financial deepening proceeds.

To examine whether the 1990s were anomalous in their behavior in this respect, we plot in Figures 10-16 the lending to GDP ratios for Indonesia, Korea, Malaysia, Philippines, Singapore, Taiwan and Thailand. The graphs show the trend lines ${ }^{10}$ for the 1985.1-89.1 and 1989.2-97.2 subperiods. The 1989.2 break is selected because this represents the last peak in US real interest rates. The subsequent decline marks the beginning of capital surges to the emerging markets.

In all cases, the rate of growth is faster in the later period than the earlier. The acceleration in credit growth is marked, except in the cases of Indonesia and Taiwan. Actually, the Indonesian exception is somewhat misleading: there is a surge of lending in 1989-90 which is not completely captured in the estimated trends. Hence, the one clear exception to the pattern of accelerating growth in the credit-GDP ratio is Taiwan.

Figures 18-23 depict the various credit ratios and 4 quarter growth rates of GDP (in log difference terms). There is not a clear pattern in the data. However, lending rises as ratio of GDP for Korea even as the GDP growth rate falls. As output growth declines from $9 \%$ to $6 \%$ in 1995-96, the lending ratios rise at an accelerating rate. At the other end of the spectrum, Taiwan does not evidence rising lending ratios during the drop in growth rates in 1995-96. The rest of the cases are indefinite. 


\subsubsection{The quality of investment projects}

Adverse selection under limited liability in financial intermediation imply that bank portfolios become progressively riskier in our model. In the aggregate, lending and investment are increasingly allocated over time to firms that have experienced low productivities in the past, rather to firms that have had high productivity experiences. If productivity has a small serial correlation, then the aggregate productivity of investment will be decreasing over time. A commonly-used aggregate statistic to measure the return to investment is the incremental capital to output ratio (ICOR). This measures the increase in the capital stock needed to produce a unit increase in output. Higher values of the ICOR suggest that the productivity of capital being put into use is low. Figure 24 presents a series of ICORs calculated from national income accounting data, taking account of business cycle factors. What is clear is that Korea, Thailand and Malaysia all exhibit high and rising ICORs, while the ratio for Indonesia is declining from very high levels to match the ICORs of Korea and Thailand. On the other hand, Taiwan once again stands out with by far the lowest ICOR. Singapore's ICOR is comparatively high, but then its emplaced capital stock per worker exceeds that of the other countries, so Singapore's values are not too surprising.

The aggregate numbers are not terribly illuminating because they confound many other factors that are not held constant in the calculations (ICORs are of the nature of total differentials). To get a less aggregate view of the situation, we also look at firm level data, drawn from two recent World Bank studies (Claessens, Djankov and Lang [1998] and Pomerleano [1998]). The series we examine are the return on assets (ROA) and the pre-tax return on capital employed (ROCE) for nonfinancial firms in the seven East Asian countries. These data are depicted in Figures 25-31.

The median ROA is calculated on the basis of samples ranging from 66 corporations in Korea in 1988 to 3567 corporations in Malaysia in 1996. In the case of sales-weighted mean ROCE, panel data ranging from 16 firms in Taiwan to 211 in Malaysia are used.

The standard caveats apply. The financial institutions and environments differ substantially across the countries, as do the levels of capital per worker. Therefore, cross-country comparisons of the levels of return on assets and return on capital must be viewed with great caution. In contrast, the within-country time series patterns may be very informative with respect to the evolution of firm (and hence investment) profitability. 
Indonesia and Thailand, two of the countries that encountered the most severe banking problems, experienced pronounced downward trends in both ROA and ROCE. As shown in Table 1, over the 1990s the ROA declined 2.9 percentage points in Indonesia, and 4.3 percentage points in Thailand. In contrast, the countries that did not experience substantial banking problems also exhibited stable or rising ROAs: Taiwan's ROA rose 1.5 percentage points, while Singapore's was essentially unchanged.

In the case of Korea the ROA only declined one percentage point over the 1990s. ${ }^{11}$ However, what is unique about Korea is that its ROA is uniformly low over the entire 1988-96 period. The Korean ROA is even below the US ROA. If we compare Korea to Taiwan, a country of comparable GDP per capita, we find that the gap between the two ROAs widens from about 1 percentage point to 3.5 percentage points over the 1990s. Hence, these statistics validate the anecdotal evidence suggesting that Korean investment expenditures deteriorated markedly in the run-up to the crisis.

\subsubsection{Bank capital}

Little time-series evidence on bank capital is available on a consistent basis. The evidence does suggest that the amount of bank capital divided by assets (the capital to asset ratio, or CAR) is inversely related to the severity of financial crisis in East Asia. In Hong Kong, the Philippines, and Singapore, the capital-asset ratios were 15-20, 15-18 and 18-22\%, respectively. In contrast, these ratios were 8-10, 6-10 and 6-10 for Indonesia, Korea and Thailand, respectively.

These CAR data are based on accounting conventions; in principle, we need to have the ratio calculated after taking into account the assets that have gone to zero value. In this case, the CARs for the first group are slightly reduced, while those for the last three countries fall to $-17,-10$, and -11 , respectively (Morgan Guaranty [1998], p.6).

\subsubsection{Contingent liabilities}

The model predicts that, in the presence of government guarantees, lending to GDP will rise; moreover, the size of contingent liabilities will also rise. These contingent liabilities represent the costs of bailing out the banking system. In theory, the share of non-performing loans (NPLs) gives a measure of the proportion of total loans that will have to be assumed by the government. In several studies, the share of NPL multiplied by the loans-to-GDP ratio has been used as a measure of the cost of bailing out the banking sector, expressed as a percentage of GDP (Corsetti, Pesenti and Roubini 
[1998a] and Burnside, Eichenbaum and Rebelo [1999]). Therefore, we anticipate observing a rising NPL share as the economy approaches the onset of a financial crisis. However, as pointed out by many observers, there are numerous ways in which to circumvent these accounting and regulatory definitions of non-performing bank assets. ${ }^{12}$

Consequently, as illustrated in Figure 32, NPL ratios provide only approximate estimates of the magnitudes of contingent liabilities, both over time and across countries. In the figure, the Thai NPL does rise in the year before the crisis. However, the Korean NPL ratio is both low and declining in the mid-1990s; the end-of-year 1996 value of NPL is $0.8 \%$ !

\subsection{Statistical tests}

We report in Column 1 of Table 3 the results of a regression of the capital flow to GDP ratio against a constant and a dummy variable over the 1989.2-1993.4 period. The dummy variable takes a value of unity for those East Asian countries that experienced a financial crisis in 1997 - Indonesia, Korea, Malaysia and Thailand. (We define a country to have suffered a financial crisis if the implied post-bailout capital-to-asset ratio is negative, according to Morgan Guaranty [1998] estimates).

The non-crisis countries averaged capital inflows of $2.8 \%$ of GDP over this period, while the crisis countries averaged $6.4 \%$. In the two years leading up to the crisis, as inflows decreased to the non-crisis countries, those to the crisis countries remained roughly the same. In other words, the gap between inflow rates widened in the run-up to July 1997 . These differences are statistically significant between the two groups, in both periods.

Lending ratios exhibit similar behavior. In both sets of countries bank lending accelerates from the 1982.1-93.4 period to the 1994.1-97.1 period. If total lending (deposit bank, other bank and nonfinancial institution lending) is considered, then the acceleration in lending is even more marked. While the growth rate in lending to GDP ratios rises from 2.8 percentage points per year to 4.7 percentage points per year in the non-crisis countries, it rises from 4.4 percentage points per year to 7.8 percentage points per year in the crisis countries.

Next we conduct an econometric investigation of the determinants of the timing and location of financial crises. We relate the onset of financial crises in the East Asian countries to corporate returns on assets (ROA) in percentages, the lagged nonperforming loan (NPL) ratios, in percentages, and 4 quarter changes in the bank lending to GDP ratios (in decimal form), over the 1995-97 period (estimating it 
over a period spanning 1998 only strengthens the results, since the ROA and NPL indicators move very strongly in the expected direction with the continuation of the crisis). The results of various specifications are reported in Table 4; the estimation technique is probit, as the dependent variable is defined as taking a value of zero, except for 1997.3- in Indonesia, Korea, Malaysia and Thailand.

If project quality declines, one should expect that bank liabilities will be increasing relative to assets, and the banks will find the bankruptcy option more and more attractive. A simple regression involving only ROA yields the correct sign on the variable, but not any statistical significance. Similarly, a regression on only NPL lagged a year also yields correctly signed but statistically insignificant coefficients. Only when the two variables are included does one obtain a significant estimate for ROA.

In many recent studies, the rate of growth of bank lending has been found to be an important determinant of a currency crisis (Kaminsky and Reinhart [1999]; Corsetti, Pesenti and Roubini [1998a];

Chinn, Dooley and Shrestha [1999]). We replace NPL with the change in the bank lending to GDP ratio to see if it proxies for the share of nonperforming loans. This variable has the anticipated (positive) sign when entered contemporaneously into the regression (column 4) or lagged two years (column 5). However, it appears that NPL has independent informational content above what is provided by lagged lending growth, as shown in column 6. In this specification, lower ROA significantly increases the probability of a financial crisis, as does a higher NPL ratio. Lagged bank lending growth has an independent effect above and beyond the NPL variable. This effect is consistent with the model's implication that increasing lending/GDP ratios will occur in economies where the public sector guarantees make bankruptcy an increasingly attractive option.

\subsection{Post-crisis events}

A consequence of financial intermediation with agency is that the model implies that output falls in the wake of the financial crisis. This is a prediction shared by many other models, so it does not differentiate this view of crises from others. The model also predicts that the output growth rate will be lower after the crisis (during recovery) than before. This pattern is evident in the data. Currency crises in our equilibrium under fixed exchange rates arise because the sudden increase in public sector budget deficit is monetized in the wake of a financial crisis, as the government realizes the contingent obligations associated with the bank bailout. Figure 33 shows that this pattern of results is more or less evident in the data. The Korean M2 to GDP ratio grows rapidly in the second and third quarters 
of 1998; so too does the Thai ratio. In both cases, some of this growth is due to the contraction in the economies. However, even if money stocks alone were examined, a similar pattern would emerge. In contrast, the Taiwanese M2 to GDP ratio remains fairly constant.

\section{Conclusion}

The theoretical model generates the endogenous accumulation of foreign debt by domestic financial sectors that ultimately becomes unsustainable leading to a banking crisis. During this process, the domestic output growth is high while foreign debt is rising in proportion to GDP. Capital inflows rise with GDP, but allocation of these resources by the banking sector becomes progressively more concentrated and risky. The banking crises portrayed by this simple agency model of financial intermediation are solvency crises and are inevitable under the policies assumed. The dynamics of twin crises in this approach are generated by anticipation of government guarantees of foreign loans or bailouts of the domestic banking industry (or both). It is also essential that these guarantees are offered, explicitly or implicitly, to the domestic financial sector without regulation of lending behavior or monitoring of market values of outstanding bank loans. The link between currency and banking crises is created by government guarantees of foreign currency debts in the event that the government abandons a pegged exchange rate. The timing of crises is indeterminate in our model (this is not a novel feature), allowing a role for contagion or panics to explain the timing or coincidence of crises. However, crises in this approach are due to fundamentals and are not due to financial panics that bring on liquidity crises.

The empirical analysis provides support for the implications of the model, although formal hypothesis testing was not possible. In particular, countries that underwent a crisis appear to experience higher rates of international capital inflows and domestic bank intermediation. External debt has played a key role in crises in countries that have been experiencing historically high rates of economic growth before the crisis. An important feature of this model is that domestic output and investment growth is high before the crisis. Countries that undergo crises tend to experience declining aggregate investment productivities before the crisis. Post-crisis events are consistent with the role of contingent government liabilities for generating financial crises. 


\section{Data Appendix}

Most of the data are from IMF, International Financial Statistics, March 1999 CD-ROM, except for data for Taiwan: Bank of China website.

$\mathrm{Q}=\log (\mathrm{X} \mathrm{CPI} / \mathrm{CPIUS})$

INTLQ $=$ INTLQ\$ $/$ XR

INTLQ\$ Foreign exchange reserves, IFS line 11.d.

$\mathrm{X}$ Exchange rates, IFS line ae, in US dollars/national currency unit, monthly, end of period.

XR Exchange rates, IFS line rf, in US dollars/national currency unit, monthly, end of period.

M1 Narrow money, IFS line 34.

M2 Broad money, M1 plus quasi-money (IFS line 35).

BC Domestic credit extended to private sector by deposit banks, IFS line 32d.

DC Domestic credit extended to private sector by all banks and/or nonbank financial institutions. For Malaysia, Philippines, Thailand, DC is the sum of IFS lines 32d and 42d. For Japan, Korea and Singapore, DC is sum of $32 \mathrm{~d}, 42 \mathrm{~d}$ and other categories of credit extended to nonfinancial private sector.

CPI Consumer price index, IFS line 64, $1990=100$.

PPI Producer price index, IFS line 63, $1990=100$.

CA \$ Current account, IFS line 78ald, quarterly rates in US dollars

CF\$ Financial account, IFS line 78bjd, quarterly rates in US dollars

ERR\$ Net errors and omissions, IFS line 78cad, quarterly rates in US dollars

I Interest rates are short term, interbank interest rates, IFS line 60b, in decimal form (average of daily rates). Data for Hong Kong is from JP Morgan up until 1993.4. The Taiwanese 3 month interest rate is from the Federal Reserve Board.

IL Bank lending rates, from IFS line 60p.

GDP Income is real GDP, IFS line 99b.r, in 1990 national currency units. The GDP series are seasonally adjusted over the 1975Q1-99Q1 periods, using the X-11 seasonal adjustment additive procedure (except for Japan, in which case the data is adjusted by Japanese statistical agencies). Taiwanese GDP is originally in 1991 New Taiwan dollars, but is rebased to 1990 units. Indonesian data is from the IMF's Indonesia country desk (provided by Ilan Goldfajn). Thai GDP is estimated using the annual relationship between GDP, exports, imports, the real exchange rate and time, and quarterly data 
on these variables to generate a quarterly GDP series. For post 1992 data, GDP data is actual quarterly GDP obtained from the Bank of Thailand website, in 1988 baht, rescaled to 1990 baht.

ICOR $=($ INV t + INV t-1)/(GDP t - GDPt-2) where INV is IFS line 93e and GDP is IFS line 99b.r (annual data). (Indonesia INV is IFS line 93).

ICORHP2 $=($ INV t + INV t-1)/(GDPHP $t$ - GDPHPt-2), where HP superscript denotes HP filtering over 1970-1997 period, using default smoothing parameter for annual data.

ROA Returns to Assets, annual data from Claessens, Djankov and Lang (1998), Table 1. In regressions using quarterly data, annual ROAs are interpolated using a moving average.

OPM Operating margin, annual data from Claessens, Djankov and Lang (1998), Table 3.

ROCE Return on Capital Employed, annual data from Pomerleano (1998), Table 10.

NPL Non performing loan ratios from Bank for International Settlements (1997), Table VI.5. Data for 1997 from Morgan Guaranty (1998) Asian Financial Markets 1998Q2, p.6, except for Taiwan, from Morgan Guaranty (1999) Asian Financial Markets 1999Q1, p. 39. 1996 observation for Singapore and Thailand from Jardine Fleming, as reported in Corsetti, Pesenti, Roubini (1998b) ”What caused...” part I, Table 21. In regressions using quarterly data, annual NPLs are arithmetically interpolated by assuming the reported NPLs apply to loan portfolios at year-end. For 1997, end-of-1996 values are assumed form 1997.1-1997.2. 


\section{References}

Bank for International Settlements [1997], Annual Report. Basle, Switzerland: Bank for International Settlements.

Bank for International Settlements [1998], Annual Report. Basle, Switzerland: Bank for International Settlements.

Bank for International Settlements [1999], Annual Report. Basle, Switzerland: Bank for International Settlements.

Bernanke, Benjamin and Mark Gertler [1990], "Financial Fragility and Economic Performance,"Quarterly Journal of Economics, 105, February, pp. 87-114.

Bernanke, Benjamin and Mark Gertler [1989], "Agency Costs, Net Worth and Business Fluctuations,” American Economic Review, 79, March, pp. 14-31.

Burnside, Craig, Martin Eichenbaum and Sergio Rebelo [1999], "Hedging and Financial Fragility in Fixed Exchange Rate Regimes, "National Bureau of Economic Research Working Paper No. 7143, May.

Caballero, Ricardo and Arvind Krishnamurthy [1998], "Emerging Markets Crises: An Assets Markets Perspective," MIT Working Paper.

Calvo, Guillermo [1998b], "Varieties of Capital-Market Crises," in Calvo, Guillermo and Mervyn King (eds.), The Debt Burden and its Consequences for Monetary Policy, London: Macmillan.

Calvo, Guillermo [1998a], "Balance of Payments Crises in Emerging Markets: Large Capital Inflows and Sovereign Governments," NBER Conference on Currency Crises, Cambridge, MA, Febuary.

Chang, Roberto and Andres Velasco [1999], "Illiquidity and Crises in Emerging Markets: Theory and Policy”, NewYorkUniversity, Working Paper.

Chinn, Menzie D., Michael P. Dooley and Sona Shrestha [1999], "Latin America and East Asia in the context of an insurance model of currency crises,"Journal of International Money and Finance, 18, pp. 659-681.

Claessens, Stijn, S. Djankov and L. Lang, [1998], "East Asian corporates: growth, financing and risks over the last decade," WorldBankPolicy Research Working Paper \#2017, World Bank: Washington, DC.

Corsetti, Giancarlo, Paolo Pesenti and Nouriel Roubini [1998a], "Paper Tigers? A preliminary assessment of the Asian crisis," Working Paper no. 6783. National Bureau of Economic Research, Cambridge, MA.

Corsetti, Giancarlo, Paolo Pesenti and Nouriel Roubini [1998b], "What caused the Asian currency 
and financial crisis? Part I: a macroeconomic overview," Working Paper no.6833. National Bureau of Economic Research, Cambridge, MA.

Corsetti, Giancarlo, Paolo Pesenti and Nouriel Roubini [1998c], "What caused the Asian currency and financial crisis? Part II: theory and policy responses," Working Paper no. 6834 National Bureau of Economic Research, Cambridge, MA.

Diamond, Douglas [1984], "Financial Intermediation and Delegated Monitoring," Review of Economic Studies, 51, pp. 393-414.

Diamond, Douglas and Phillip Dybvig [1983], "Bank Runs, Deposit Insurance and Liquidity," Journal of Political Economy, 91, June, pp. 401-419.

Dooley, Michael P. [1999], A model of crises in emerging markets,” Economic Journal, forthcoming.

Edwards, Sebastian and Carlos Vegh [1997], "Banks and Macroeconomic Disturbances under Predetermined Exchange Rates,” Journal of Macroeconomics, 40, pp. 239-278.

Eichengreen, Barry and Andrew Rose [1998], "Staying afloat when the wind shifts: External factors and emerging-market banking crises," Working Paper no. 6370. National Bureau of Economic Research, Cambridge, MA.

Flood, Robert and Peter Garber [1984], "Collapsing Exchange Rate Regimes: Some Linear Examples," Journal of International Economics, 17, August,

Frankel, Jeffrey and Andrew Rose [1996], "Currency crashes in emerging markets: An empirical treatment," Journal of International Economics, 41, pp. 351-368.

Furman, Jason and Joseph Stiglitz [1998], "Economic Crises: Evidence and Insights from East Asia,” Brookings Papers on Economic Activity, 2, pp. 1-115.

Glick, Reuven and Michael Hutchison [1999], "Banking and Currency Crises: How Common are Twins ¿’ Federal Reserve Bank of San Francisco, manuscript, June.

Goldfajn, Ilan and Rodrigo Valdes [1997], "Capital Flows and the Twin Crises: The Role of Liquidity," International Monetary Fund, Working Paper WP/97/87.

Hutchison, Michael and Kathleen McDill [1998], "Determinants, costs and duration of banking sector distress: The Japanese experience in international comparison," paper presented at the NBER-TCER Japan Project Meeting, Tokyo, October.

Kaminsky, Graciela and Carmen Reinhart [1998], "Currency and banking crises: The early warnings of distress," International Finance Discussion Paper no. 629, Board of Governors of the Federal Reserve System, Washington, D.C.

Kaminsky, Graciela and Carmen Reinhart [1999], "The Twin Crises: The Causes of Banking and 
Balance-of-Payments Problems,"American Economic Review, forthcoming.

Kiyotaki, Nobuhiro and John Moore [1997], “Credit Cycles,” Journal of Political Economy, 105, pp. 211-248.

Krugman, Paul [1979], “A Model of Balance-of-Payments Crises,” Journal of Money, Credit and Banking, 11, August, pp. 311-325.

Krugman, Paul [1998], "Bubble, boom, crash: Theoretical notes on Asia's crisis," MIT, Cambridge, MA. Unpublished.pp. 1-13.

Kumhof, Michael [1998], "Balance of Payments Crises: The Role of Short-Term Debt," manuscript, Stanford University.

McKinnon, Ronald and Huw Pill [1999], "Credible liberalizations and international capital flows: The overborrowing syndrome," in Ito, T., Krueger, A.O. (eds.) Financial Deregulation and Integration in East Asia. Chicago: University of Chicago Press.

Miller, Marcus and Joseph Stiglitz [1999], "Bankruptcy Protection Against Macroeconomics Shocks: The case for a 'super Chapter 11'," Centre for the Study of Globalisation and Regionalisation, University of Warwick, manuscript, April.

Mishkin, Frederic [1996], "Understanding Financial Crises: A Developing Country Perspective," in Bruno, Michael and Boris Pleskovic (eds.), Annual World Bank Conference on Development Economics 1996, Washington, D.C.: The World Bank, pp. 29-62.

Moreno, Ramon [1996], "Intervention, sterilization, and monetary control in Korea and Taiwan," Federal Reserve Bank of San Francisco Economic Review 1996(3), pp. 23-33.

Morgan Guaranty Trust Company [1998], Asian Financial Markets, 2nd Qtr., New York: J.P. Morgan.

Morgan Guaranty Trust Company [1999], Asian Financial Markets, 1st Qtr., New York: J.P. Morgan.

Obstfeld, Maurice [1998], “The Global Capital Market: Benefactor of Menace?” Journal of Economic Perspectives, 12, pp. 9-30.

Pomerleano, M. [1998], "The East Asian crisis and corporate finances: the untold micro story," World Bank Policy Research Working Paper \#1990, World Bank: Washington, DC.

Sachs, Jeffrey, Aaron Tornell and Andres Velasco [1996], "Financial crises in emerging markets: The lessons from 1995," Brookings Papers on Economic Activity, pp. 147-215.

Spiegel, Mark M. [1995], "Sterilization of capital inflows through the banking sector: evidence from Asia," Federal Reserve Bank of San Francisco, manuscript. 
Stiglitz, Joseph and Andrew Weiss[1981], "Credit Rationing in Markets with Imperfect Information,” American Economic Review, 71, pp. 393-410. 


\section{Endnotes}

${ }^{1}$ The empirical relationship between these "twin crises" is the subject of Kaminsky and Reinhart [1998 and 1999], Hutchison and McDill [1999] and Glick and Hutchison [1999].

${ }^{2}$ This link between contingent government liabilities and currency crises is also used by Calvo [1998a], Burnside, Eichenbaum and Rebelo [1999], Chinn, Dooley and Shrestha [1999] and Dooley [1999].

${ }^{3}$ Examples responsive to the Asian Crisis of 1997 include Caballero and Krishnamurthy [1998], Chang and Velasco [1999], Dooley [1999], Eichengreen and Rose [1998], Furman and Stiglitz [1998], Goldfajn and Valdes [1997], Kumhof [1998], Krugman [1998], McKinnon and Pill [1999] and Miller and Stiglitz [1999]. Other recent papers on international capital flows to emerging markets include Edwards and Vegh [1997], Frankel and Rose [1996], Sachs and Tornell and Velasco [1996], among others.

${ }^{4} \mathrm{We}$ do not pursue any such explanations of the timing of a crisis once one is viable.

${ }^{5}$ For simplicity, we have left out elements of a model that would make this a welfare-improving policy. If the model were extended to incorporate time-to-build into the production process and market incompleteness as in Diamond and Dybvig [1983], then deposit insurance could be justified on welfare grounds.

${ }^{6}$ The portfolio dynamics of the banks demonstrated here imply that bank portfolios will become dominated by lending to firms that are no longer self-financing in any part.

${ }^{7}$ The income risk facing households is not the same as in a basic stochastic AK model. Therefore, we do not state that isoelastic utility is a sufficient condition for consumption growth to equal investment and output growth, although this may turn out to be true.

${ }^{8}$ We do not preclude banks lending to each other. Since they can do so, what matters is the aggregate solvency of the banking sector and not the solvency of individual banks.

${ }^{9}$ The indeterminancy of the timing of the attack because $D_{t}$ is endogenous can be seen by adding a Cagan-style money demand equation. In that case, the difference between household deposits at the beginning of period $t$ and the reserves demanded by households in the attack during period $t$ will equal 
their demand for money given the rate of devaluation implied by $D_{t}$. At the time of an attack on the currency peg,

$$
b_{t}-m^{d}\left(D_{t}\right)+f_{t}=R_{t}+D_{t},
$$

where $R_{t}$ represents reserves.

${ }^{10}$ The trend lines are estimated by regressing the first difference of the credit to GDP ratio on a constant and a dummy variable taking on a value of one beginning in 1989.2, and then dynamically forecasting from the beginning of the sample using the estimated equation.

${ }^{11}$ The Korean ROCE actually rose up to 1995 (the last year for which data is available). However, these ROCE statistics are based on a particularly small panel of only 66 corporations; hence we rely more upon the longer, ROA series for inference.

${ }^{12}$ See Morgan Guaranty [1998], p.8 for a table describing the accounting and prudential standards for Indonesia, Japan, Malaysia, Korea and Thailand. 


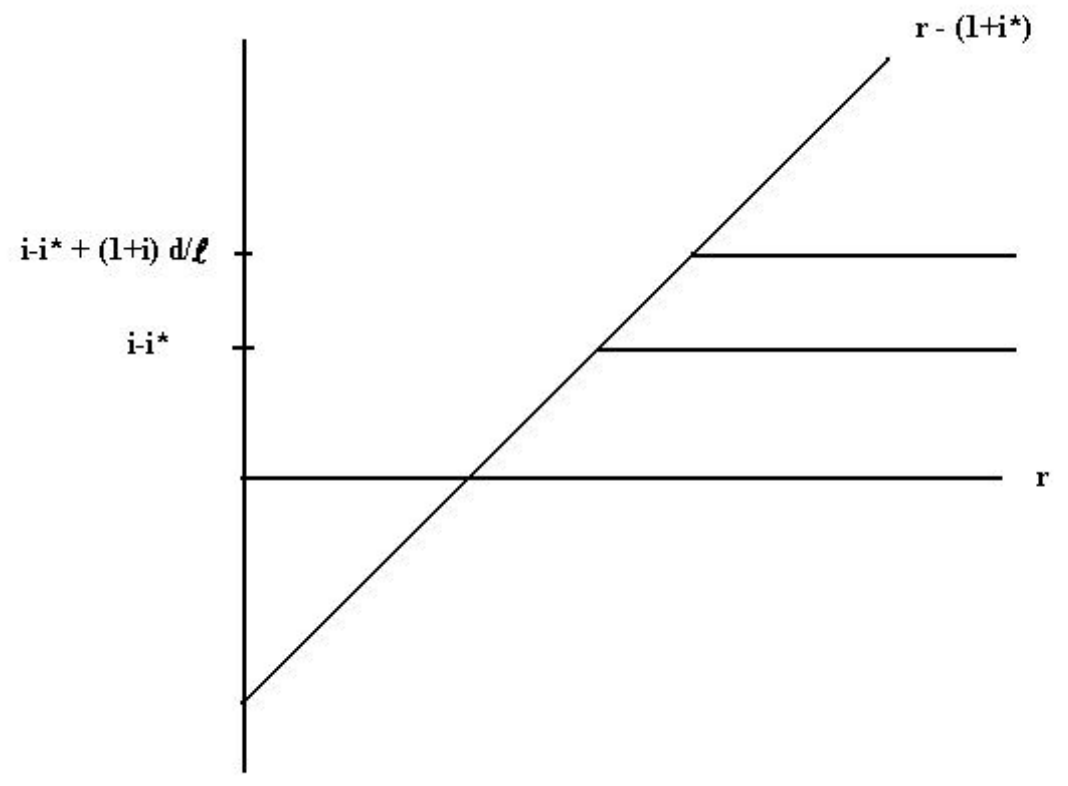

Figure 1: Bank returns as a function of project returns.

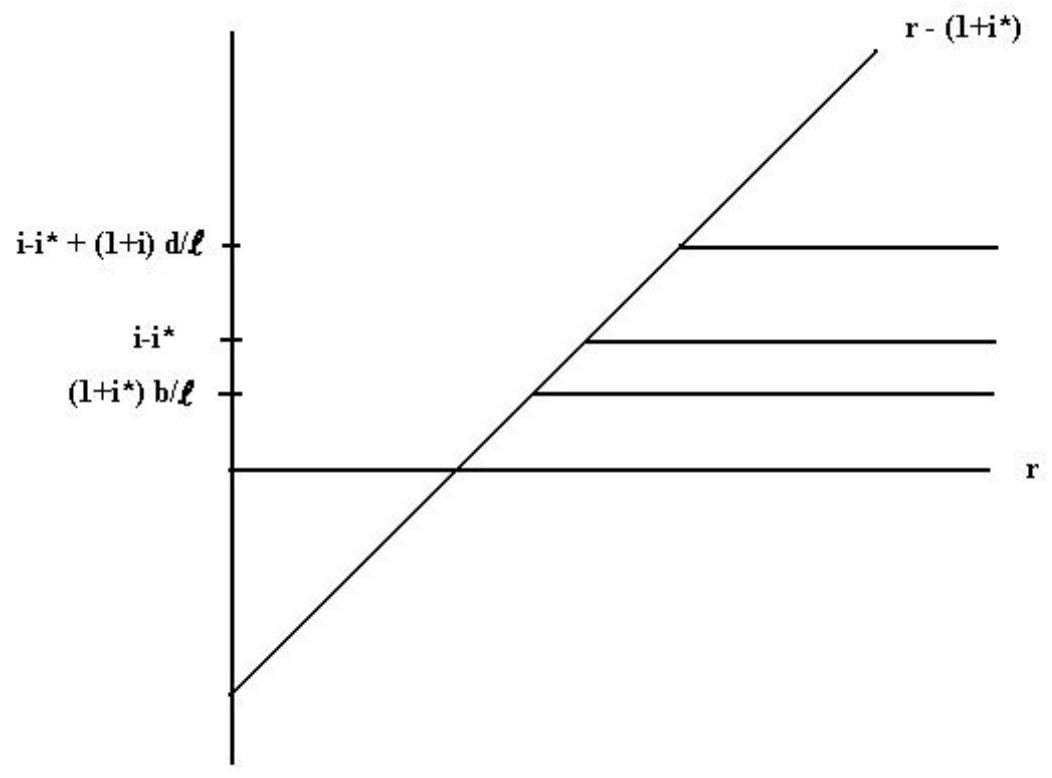

Figure 2: Bank returns with foreign borrowing. 


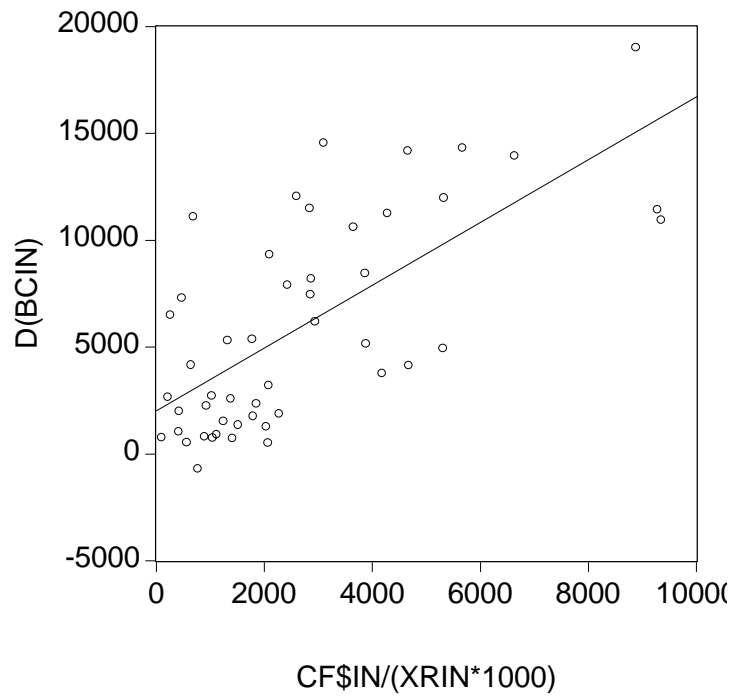

Figure 3: Indonesia, change in deposit bank credit against capital inflows, billions of rupiah.

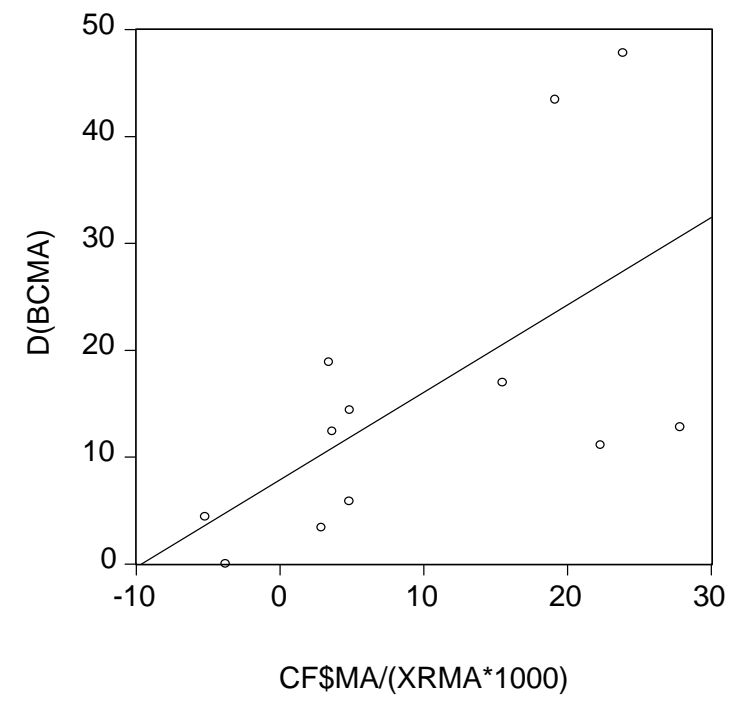

Figure 5: Malaysia, annual change in bank credit against annual capital inflows, in billions of ringgit.

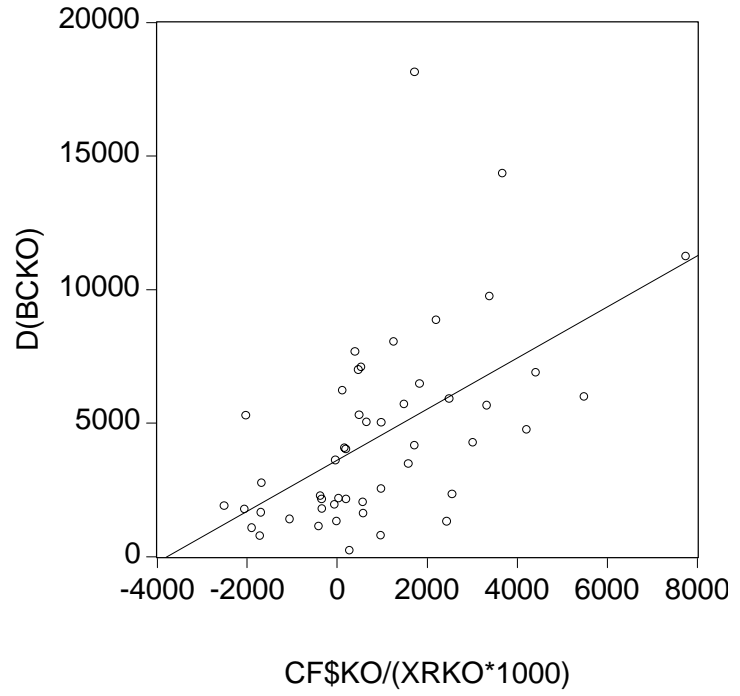

Figure 4: Korea, change in deposit bank credit against capital inflows, billions of won.

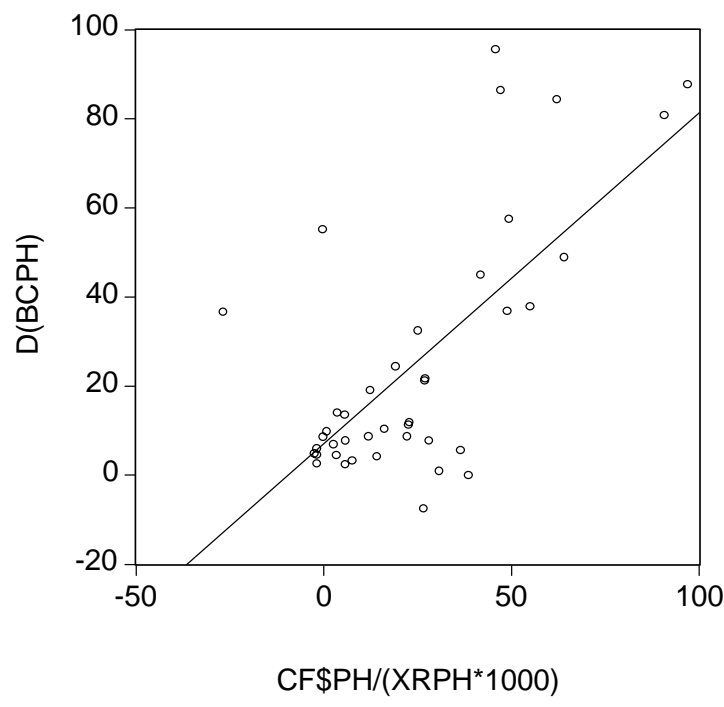

Figure 6: Philippines, change in bank credit against capital inflows, in billions of pesos. 


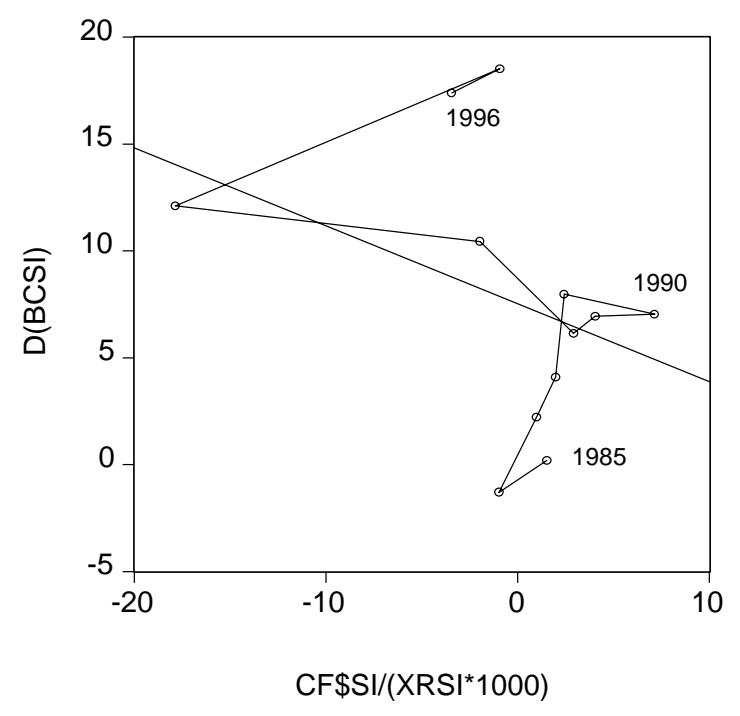

Figure 7: Singapore, annual change in bank credit against annual capital inflows, in billions of Singapore dollars.

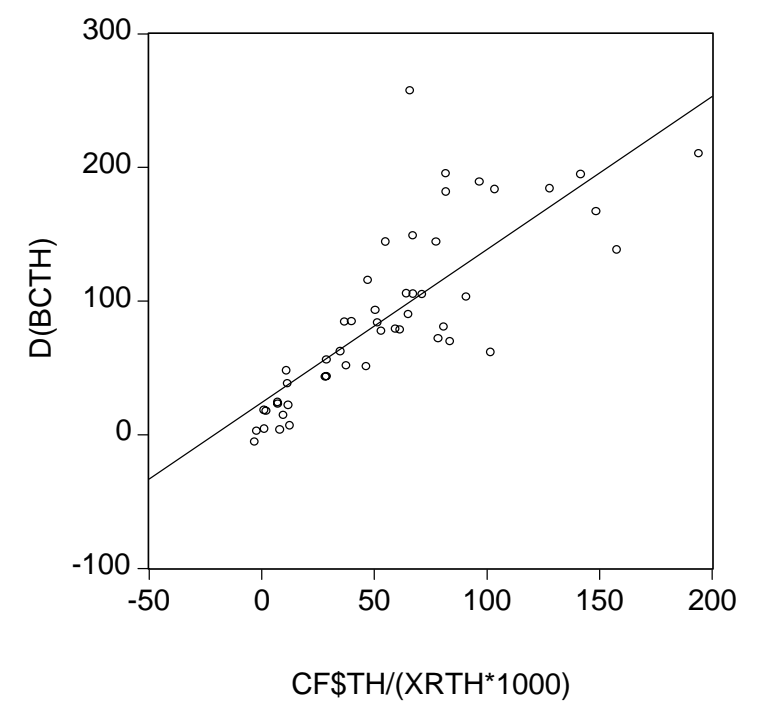

Figure 9: Thailand, change in bank credit against capital inflows, in billions of baht.

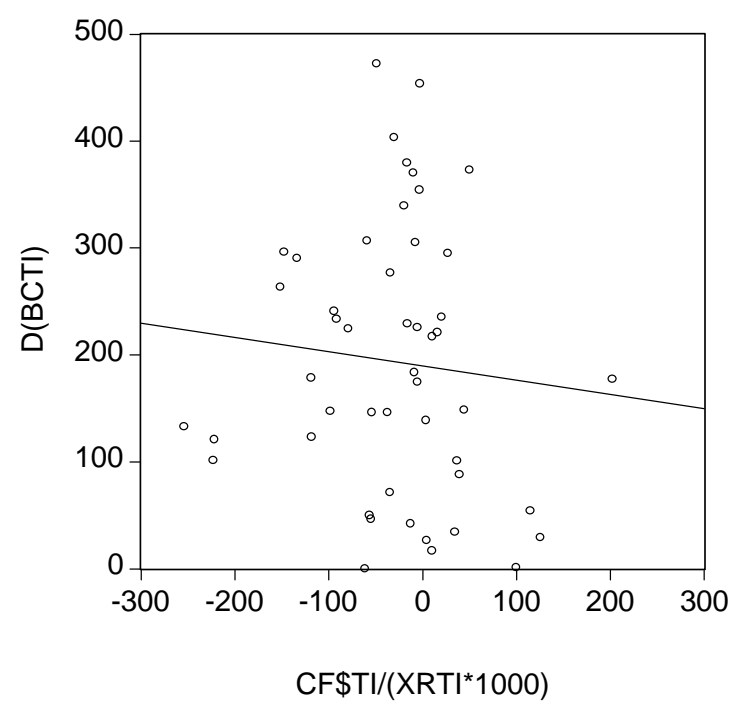

Figure 8: Taiwan, change in bank credit against capital inflows, in billions of $\mathrm{New}$ Taiwan dollars. 


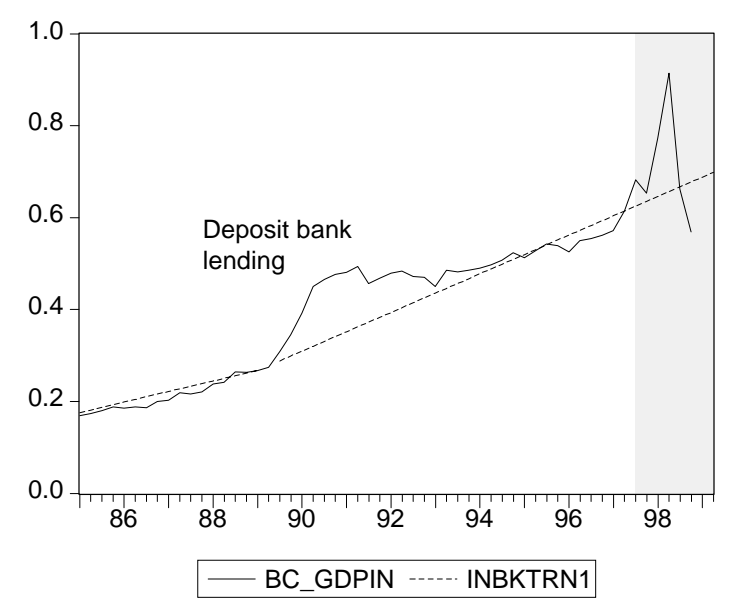

Figure 10: Indonesia, deposit bank lending to GDP ratio and segmented trends.

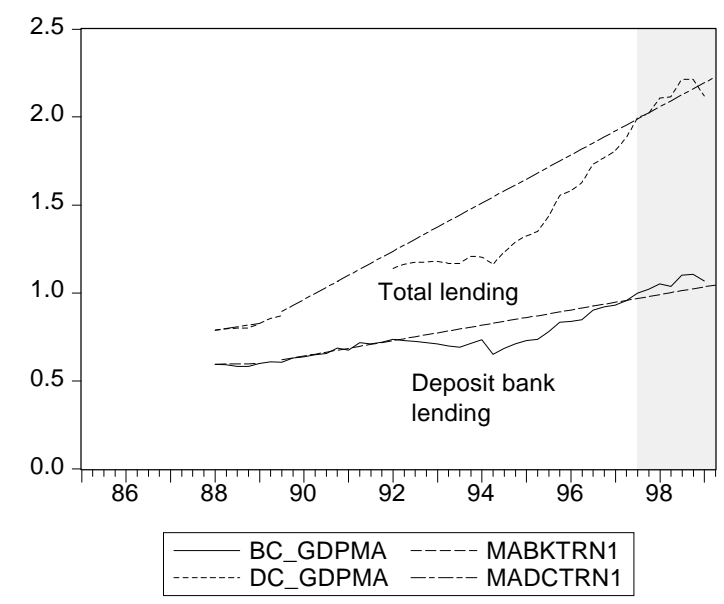

Figure 12: Malaysia, deposit bank and total lending to GDP ratios, and segmented trends.

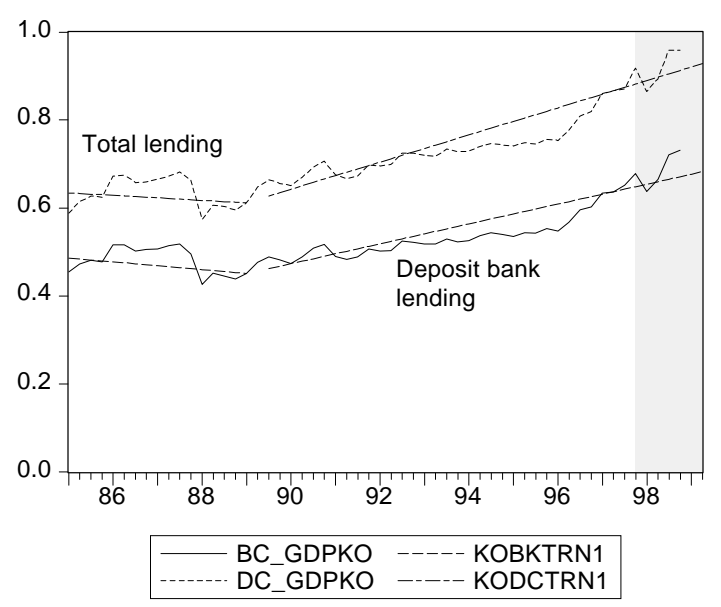

Figure 11: Korea, deposit bank and total lending to GDP ratios, and segmented trends.

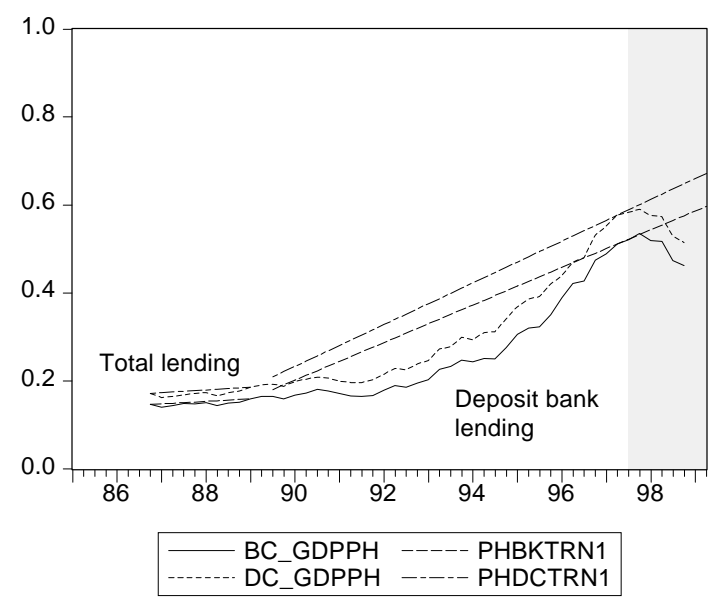

Figure 13: Philippines, deposit bank and total lending to GDP ratios, and segmented trends. 


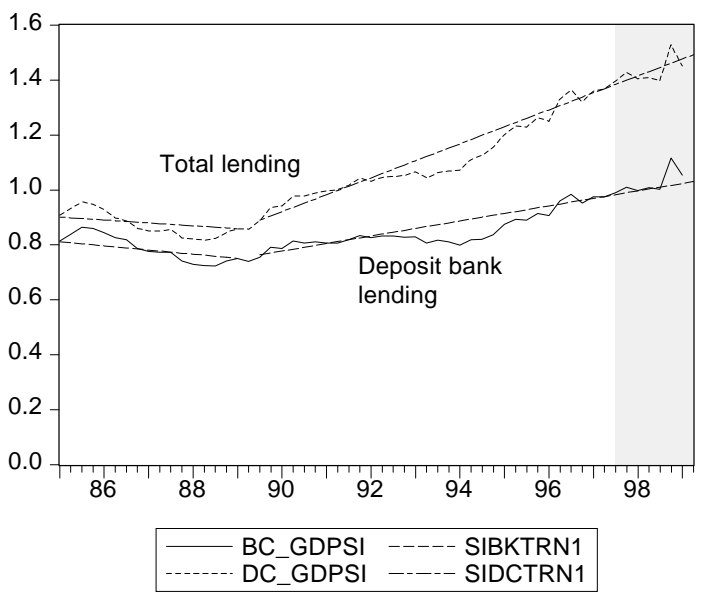

Figure 14: Singapore, deposit bank and total lending to GDP ratios, and segmented trends.

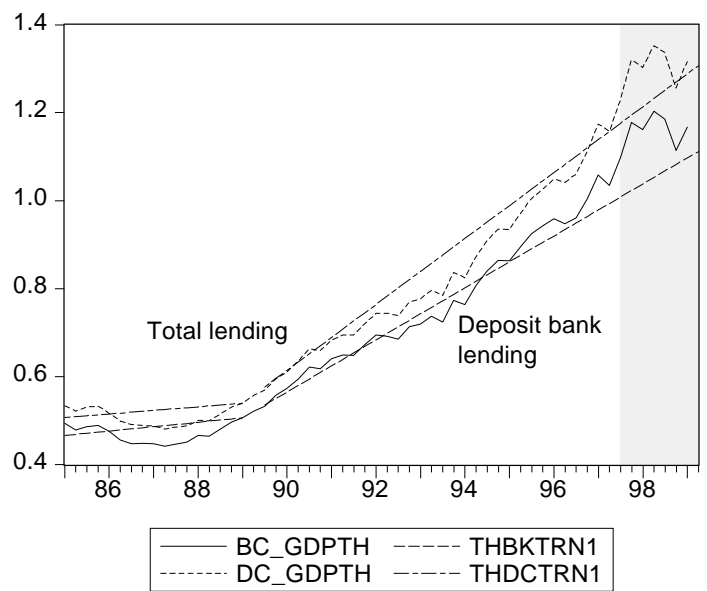

Figure 16: Thailand, deposit bank and total lending to GDP ratios, and segmented trends.

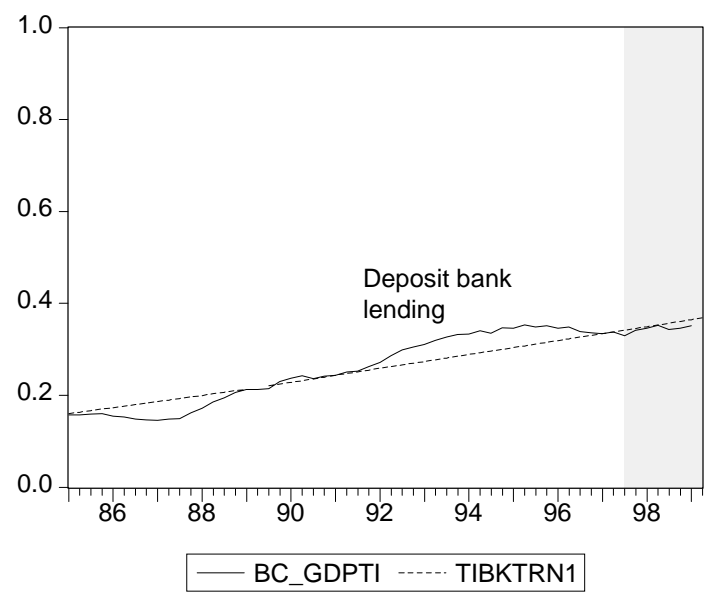

Figure 15: Taiwan, deposit bank lending to GDP ratio and segmented trends. 


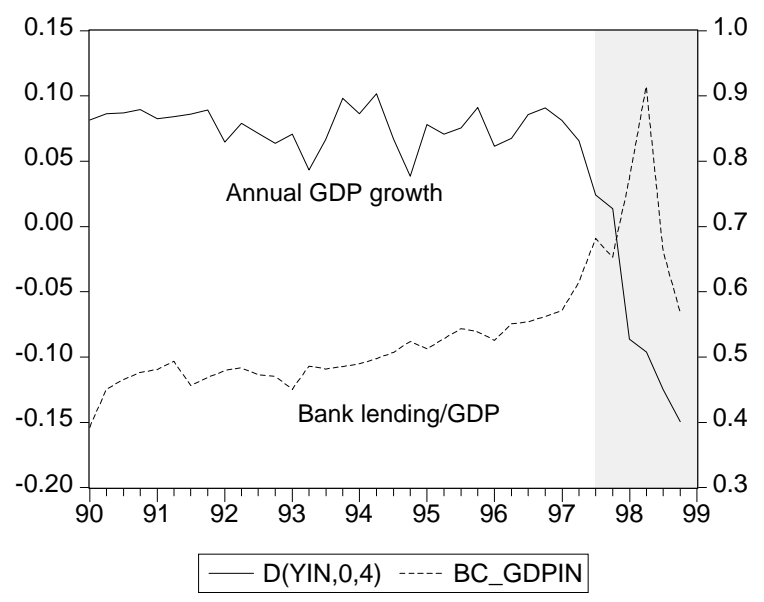

Figure 18: Indonesia, annual GDP growth rate and bank lending to GDP ratio.

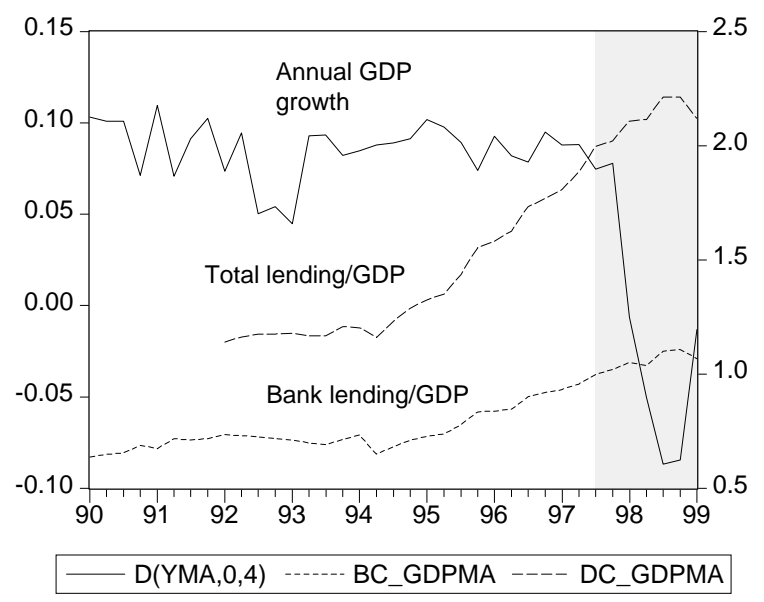

Figure 19: Malaysia, annual GDP growth rate and deposit bank and total lending to GDP ratios.

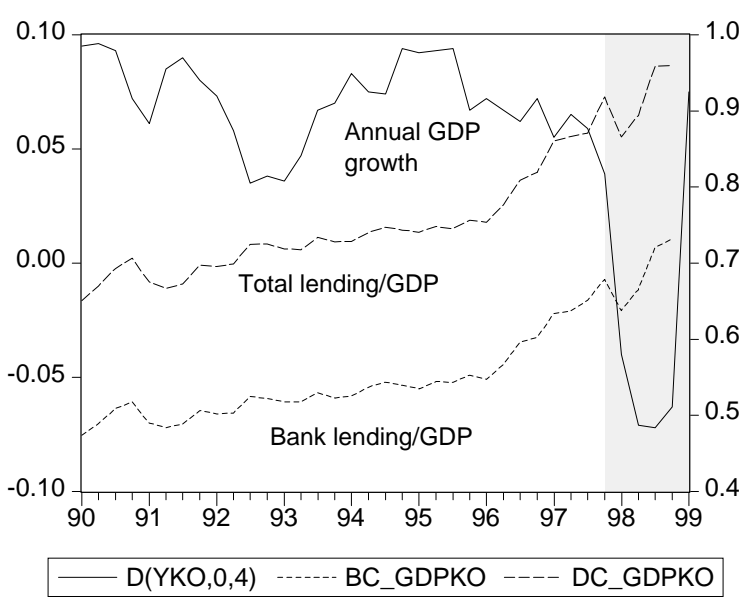

Figure 17: Korea, annual GDP growth rate and deposit bank and total lending to GDP ratios.

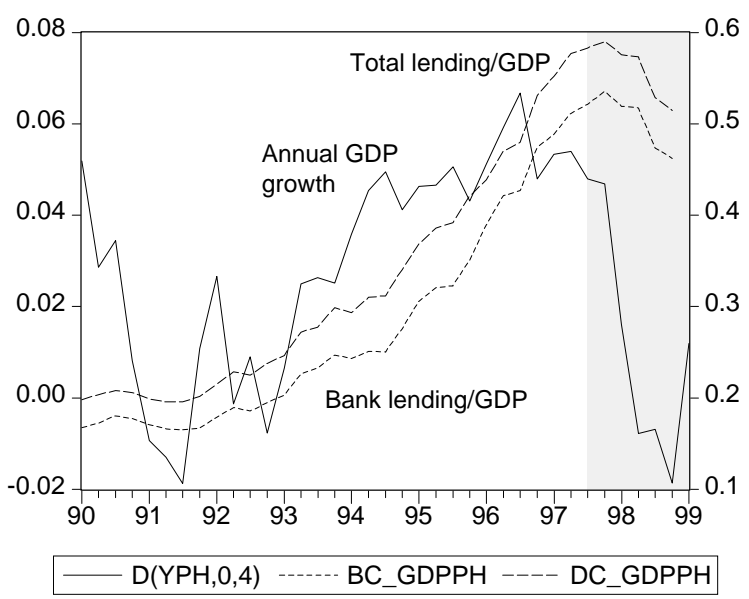

Figure 20: Philippines, annual GDP growth rate and deposit bank and total lending to GDP ratios. 


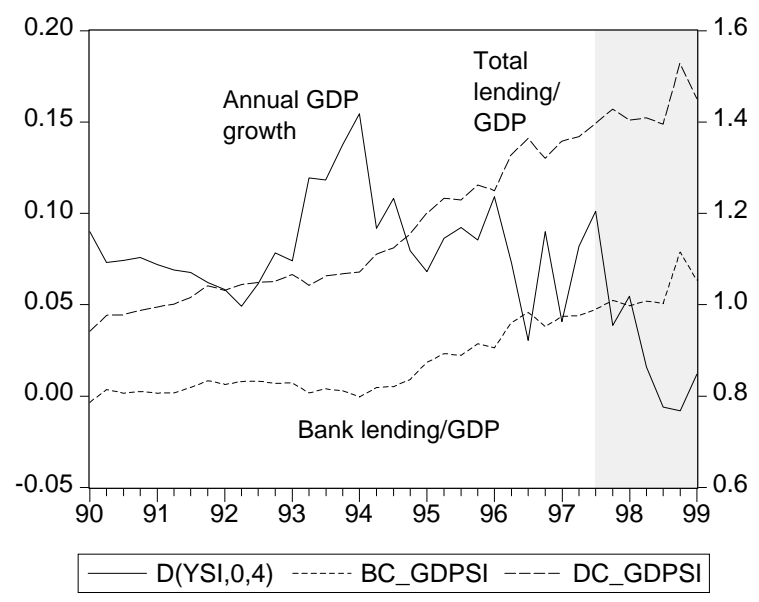

Figure 21: Singapore, annual GDP growth rate and deposit bank and total lending to GDP ratios.

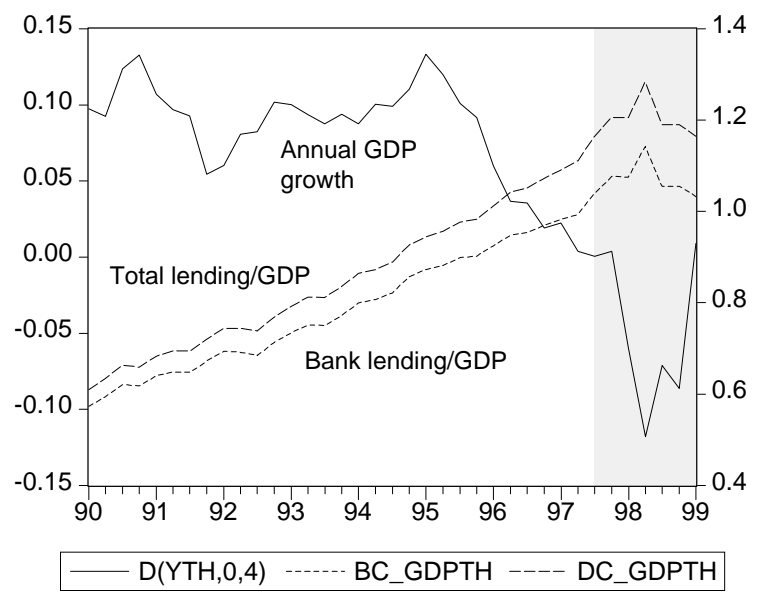

Figure 23: Thailand, annual GDP growth rate and deposit bank and total lending to GDP ratios.

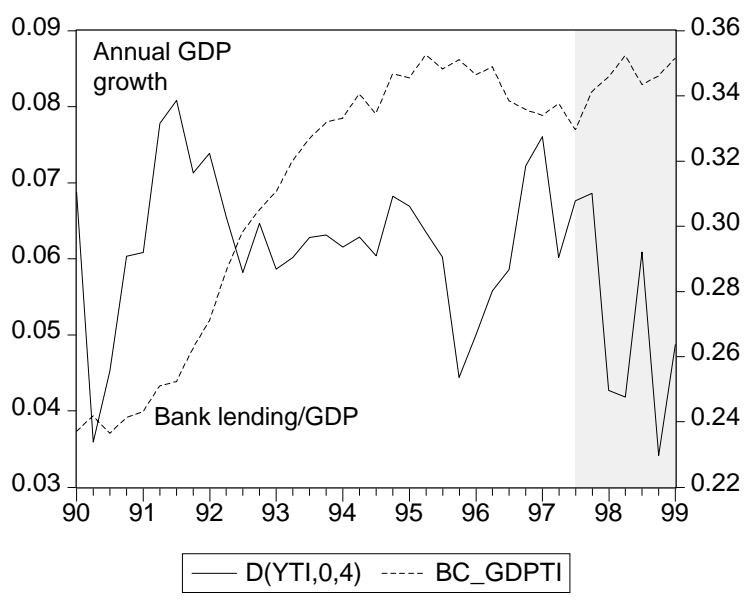

Figure 22: Taiwan, annual GDP growth rate and deposit bank lending to GDP ratio. 

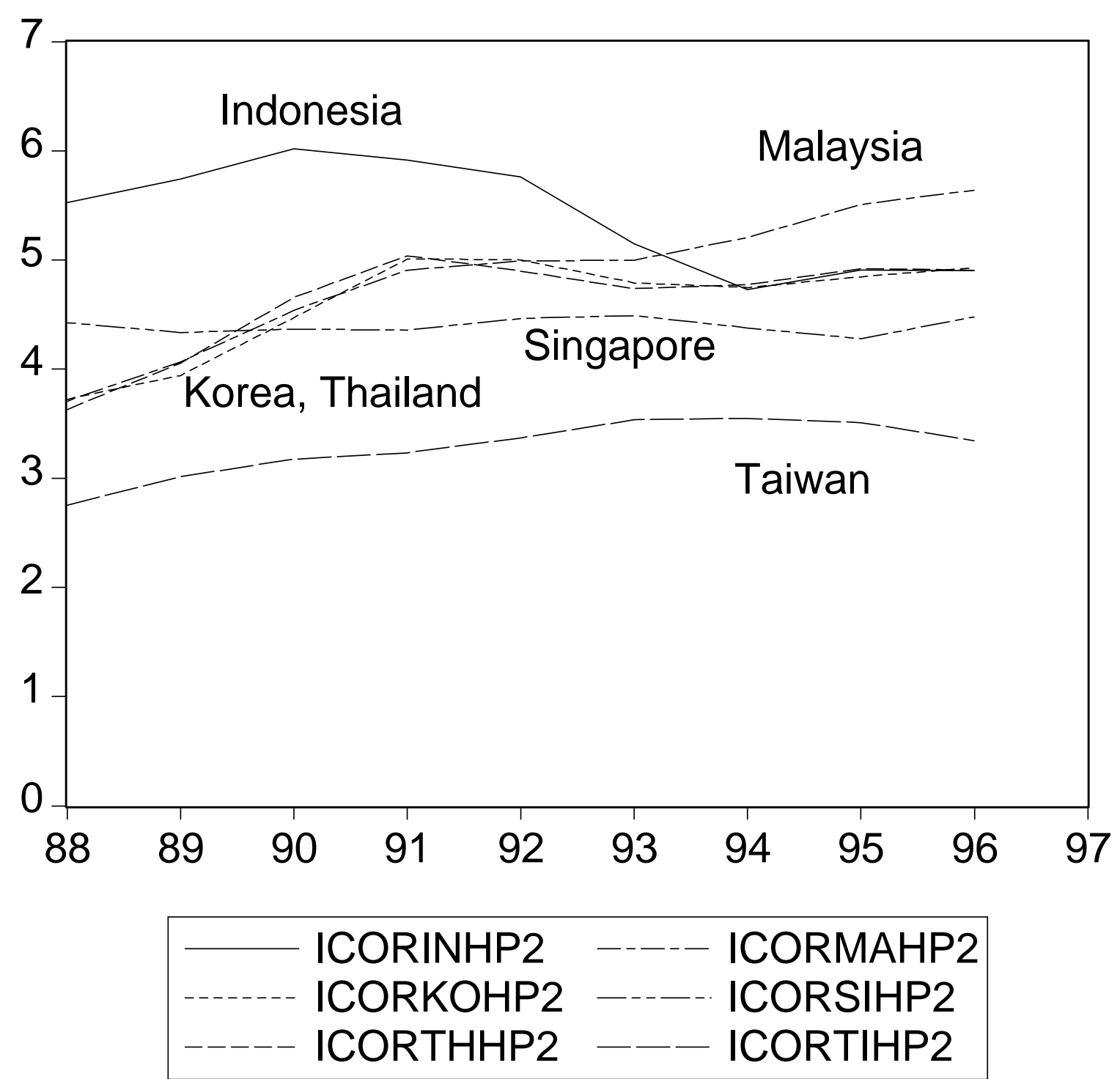

Figure 24: Incremental capital-to-output ratios (ICORs) for Indonesia, Korea, Thailand, Malaysia, Singapore and Taiwan (based on two-year changes and detrended GDP data). 


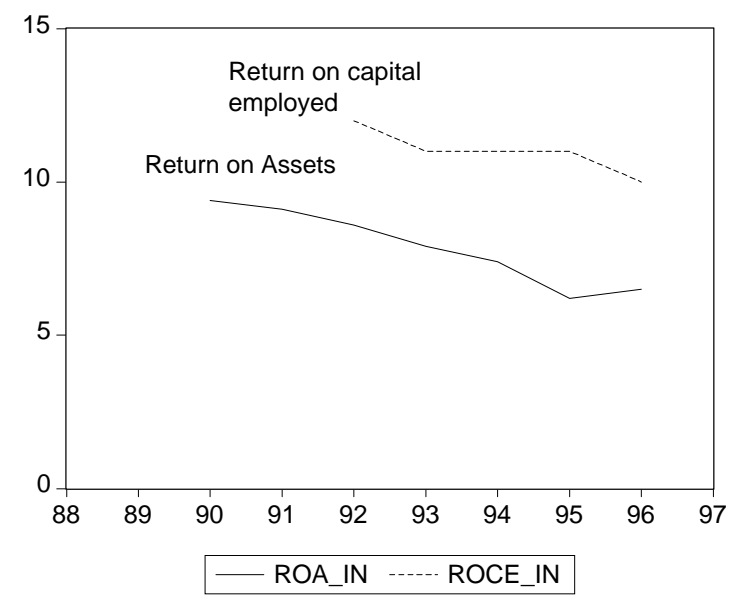

Figure 25: Indonesia, Return on Assets and Return on Capital Employed.

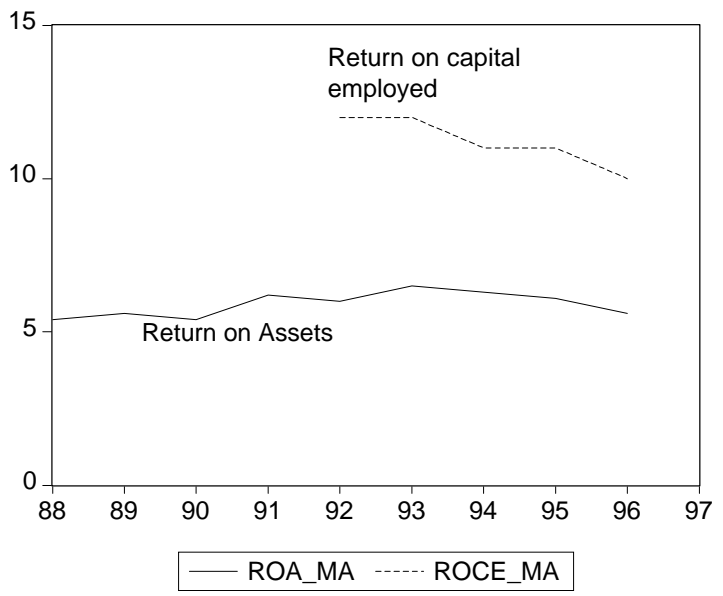

Figure 27: Malaysia, Return on Assets and Return on Capital Employed.

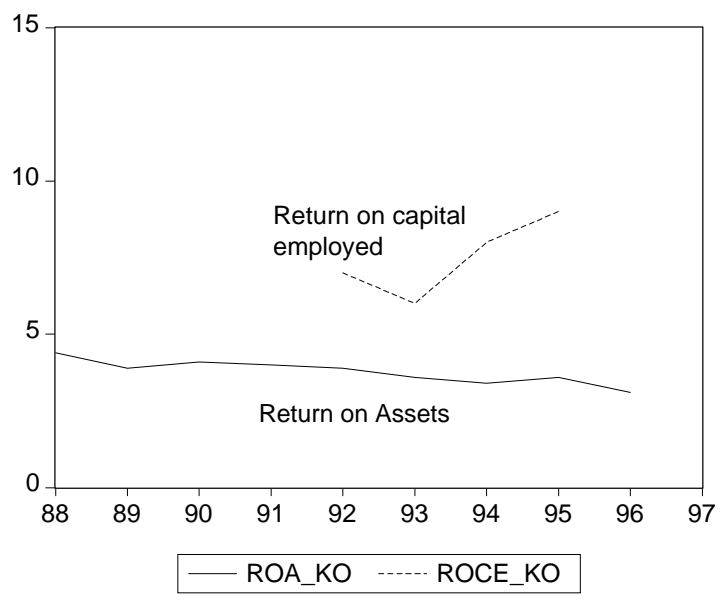

Figure 26: Korea, Return on Assets and Return on Capital Employed.

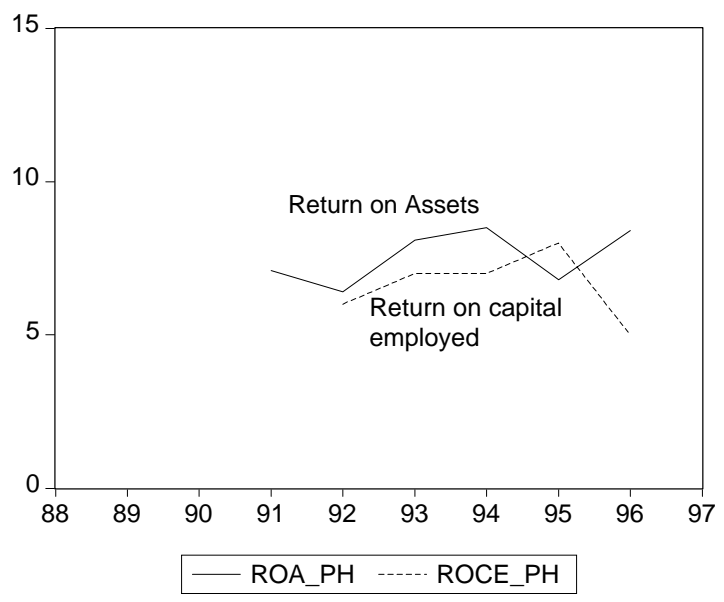

Figure 28: Philippines, Return on Assets and Return on Capital Employed. 


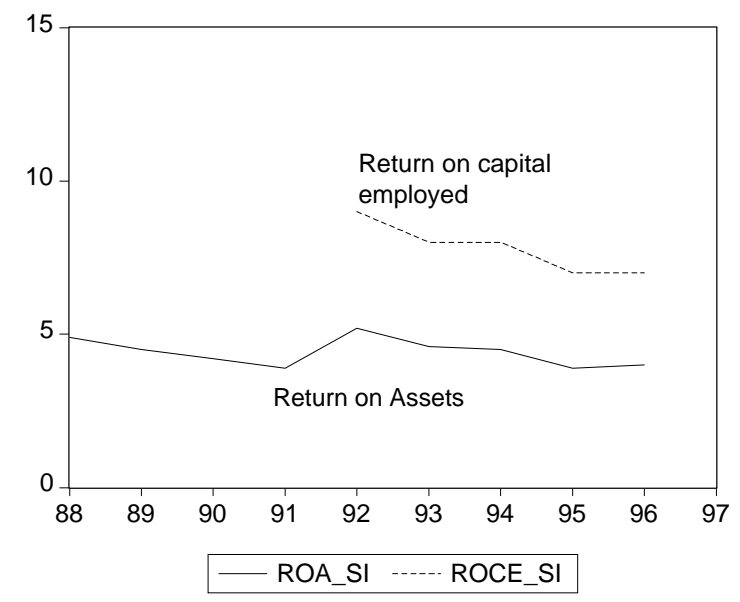

Figure 29: Singapore, Return on Assets and Return on Capital Employed.

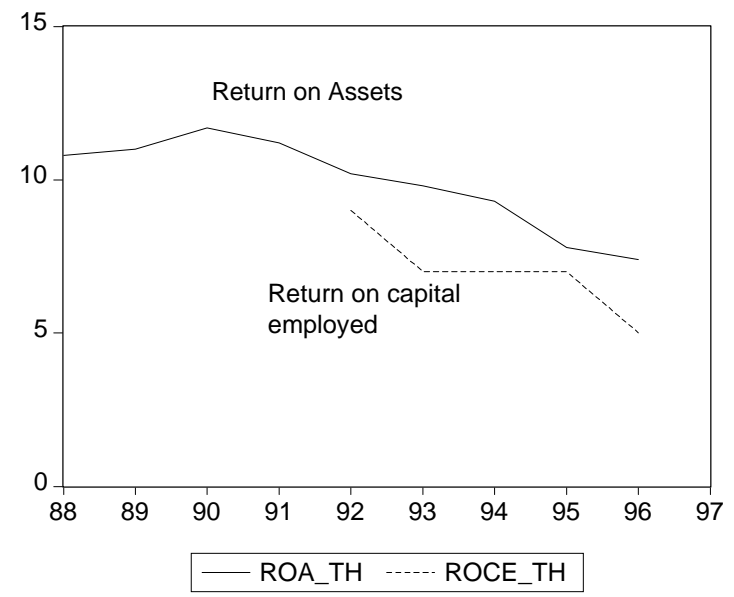

Figure 31: Thailand, Return on Assets and Return on Capital Employed.

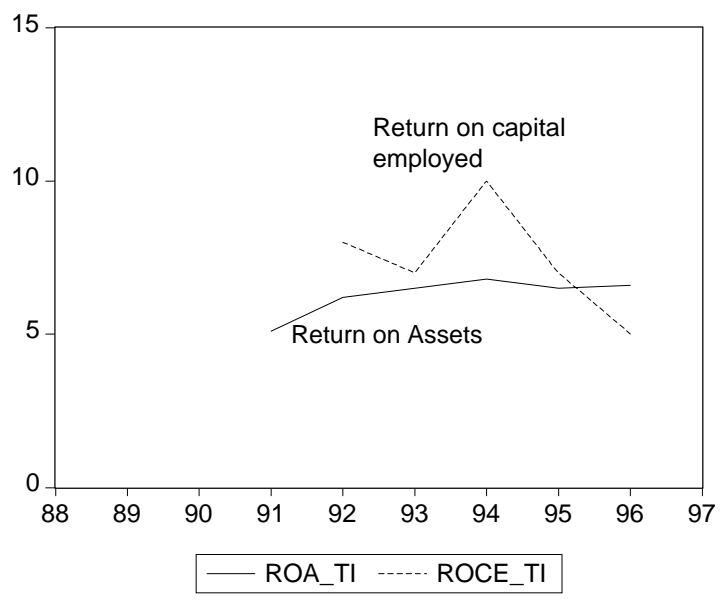

Figure 30: Taiwan, Return on Assets and Return on Capital Employed. 


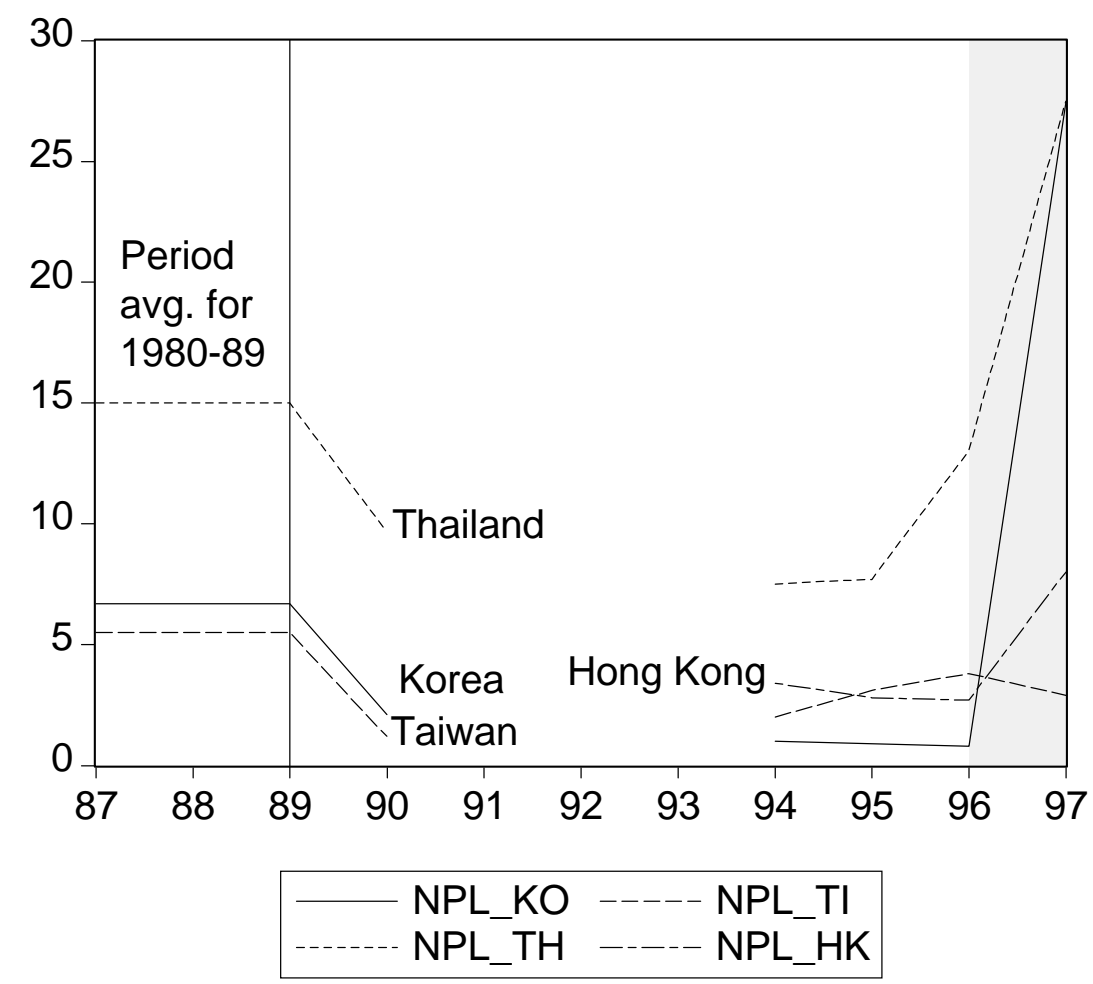

Figure 32: Non-Performing Loan ratios (in percent) for Korea, Thailand, Taiwan and Hong Kong.

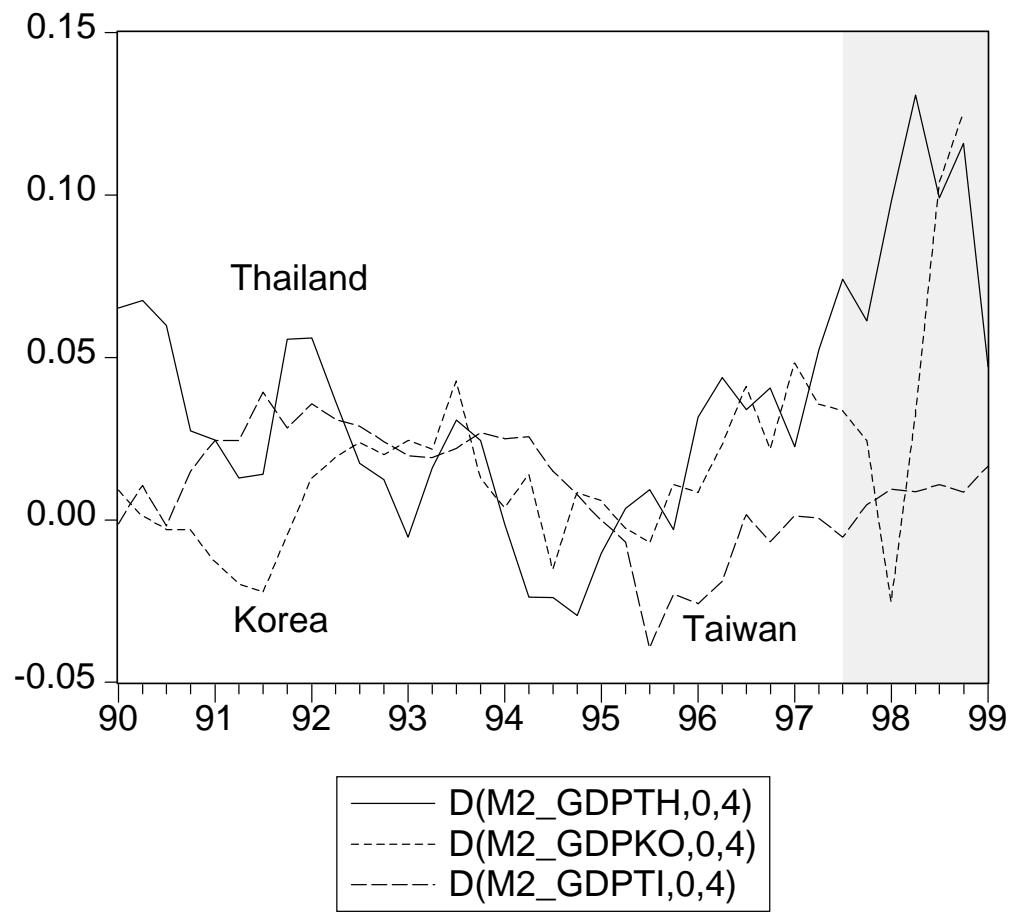

Figure 33: Annual growth rates of the M2 to GDP ratios for Thailand, Korea and Taiwan. 
Table 1

Lending to GDP Ratio Growth Rates

1985.1 to 1997.2

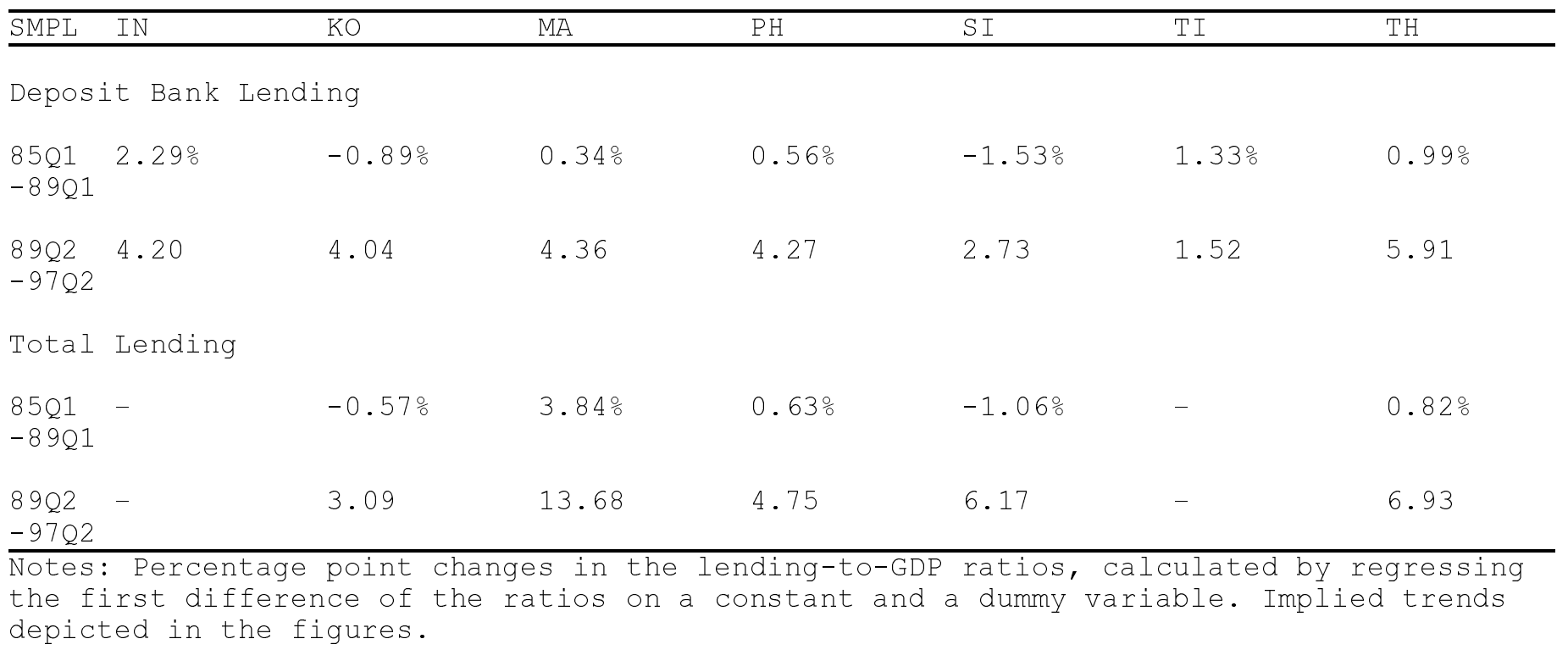


Table 2

Return on Assets

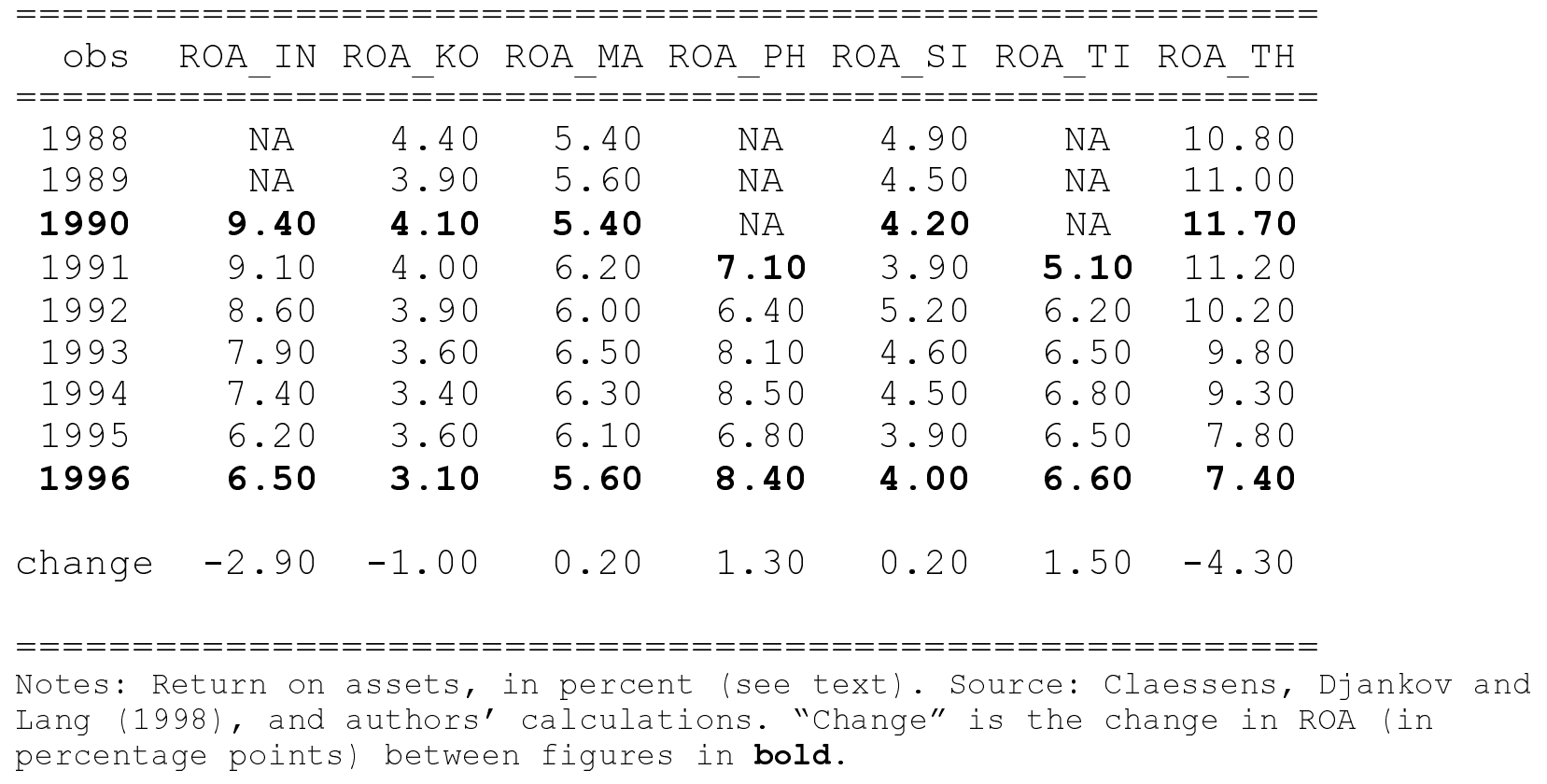


Table 3

Capital Inflows and Lending in Non-Crisis and Crisis Countries 1989.2-1993.4 and 1994.1-1997.1

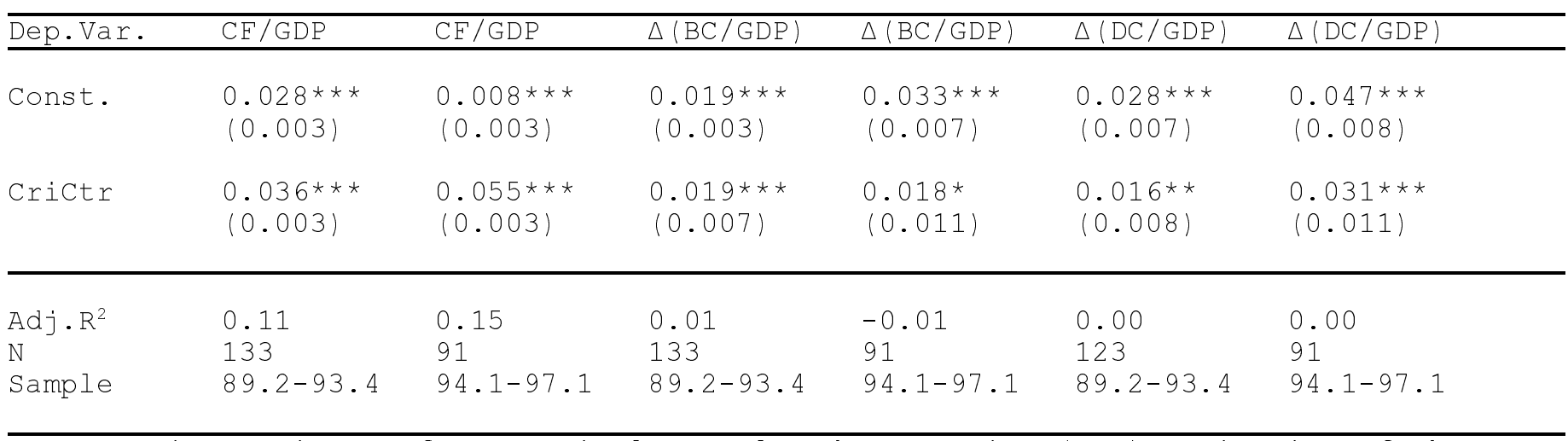

Notes: Point estimates from seemingly unrelated regression (SUR) estimation of the dependent variable (expressed in decimal form) on a constant and a dummy variable. Countries included are Indonesia, Korea, Malaysia, Philippines, Singapore, Taiwan and Thailand. The dummy variable Crictr takes on a value of unity for Indonesia, Korea, Malaysia and Thailand. $\triangle(B C / G D P)$ is the annualized first difference of the bank lending to GDP ratio. * $(* *)[* * *$ ] denotes significance at the 10\%(5\%)[1\%] MSL. Capital flow to GDP ratios for Malaysia and Singapore are annual averages. 
Table 4

Determinants of Financial Crises

1995.1-1997.4

Dependent Variable: Financial Crisis

\begin{tabular}{|c|c|c|c|c|c|c|}
\hline $\mathrm{ROA}$ & $\begin{array}{c}-0.120 \\
(0.097)\end{array}$ & - & $\begin{array}{c}-0.407 \star \\
(0.249)\end{array}$ & $\begin{array}{c}-0.193 \\
(0.126)\end{array}$ & $\begin{array}{l}-0.204 * \star \star \\
(0.103)\end{array}$ & $\begin{array}{c}-0.538 * \star \\
(0.243)\end{array}$ \\
\hline NPL $\quad t-4$ & & $\begin{array}{l}0.041 \\
(0.057)\end{array}$ & $\begin{array}{l}0.136 \\
(0.088)\end{array}$ & - & - & $\begin{array}{l}0.152 * \\
(0.086)\end{array}$ \\
\hline$\triangle(\mathrm{BC} / \mathrm{GDP})$ & & & & $\begin{array}{l}18.033 * * * \\
(5.633)\end{array}$ & - & - \\
\hline$\Delta(\mathrm{BC} / \mathrm{GDP})_{\mathrm{t}-8}$ & & & & & $\begin{array}{l}10.075 * * \\
(4.809)\end{array}$ & $\begin{array}{l}10.281 * \star \\
(4.951)\end{array}$ \\
\hline $\begin{array}{l}\mathrm{Adj} \cdot \mathrm{R}^{2} \\
\mathrm{~N}\end{array}$ & $\begin{array}{l}0.02 \\
96\end{array}$ & $\begin{array}{l}0.32 \\
70\end{array}$ & $\begin{array}{l}0.09 \\
70\end{array}$ & $\begin{array}{l}0.23 \\
96\end{array}$ & $\begin{array}{l}0.10 \\
90\end{array}$ & $\begin{array}{l}0.17 \\
67\end{array}$ \\
\hline \multicolumn{7}{|c|}{$\begin{array}{l}\text { Notes: Point estimates from probit estimation of the dependent variable (Huber-White } \\
\text { robust standard errors in parentheses). Countries included are Hong Kong, Indonesia, } \\
\text { Korea, Malaysia, Philippines, Singapore, Taiwan and Thailand. ROA is the Return On } \\
\text { Assets from Claessens et al. (1998) interpolated. NPL is the Non-Performing Loan ratio } \\
\text { (in percent) from BIS (1997) and other sources. } \triangle \text { (BC/GDP) is the } 4 \text { quarter change in the } \\
\text { bank lending to GDP ratio. * }(* *) \text { [**] denotes significance at the 10\%(5\%)[1\%] MSL. }\end{array}$} \\
\hline
\end{tabular}

